\title{
The dynamics of mangrove ecosystems, changes in sea level and the strategies of Neolithic settlements along the coast of Oman (6000-3000 cal. BC)
}

\author{
J.F. Berger ${ }^{\mathrm{a}, *}$, V. Charpentier ${ }^{\mathrm{b}}$, R. Crassard $^{\mathrm{c}}$, C. Martin $^{\mathrm{d}}$, G. Davtian ${ }^{\mathrm{e}}$, J.A. López-Sáez ${ }^{\mathrm{f}}$ \\ ${ }^{a}$ CNRS, UMR 5600 EVS, IRG, Université Lyon 2, 69676 BRON, France \\ ${ }^{\mathrm{b}}$ Inrap, MAE-UMR ARSCAN, Nanterre, France \\ ${ }^{\mathrm{c}}$ CNRS, MOM-UMR 5133 Archéorient, Lyon, France \\ ${ }^{\mathrm{d}} \mathrm{MNHN}$, Paris, France \\ e CNRS, UMR 7264, Cepam-Université de Nice, France \\ ${ }^{\mathrm{f}}$ CSIC, Grupo de Investigación 'Arqueobiología', Instituto de Historia, Madrid, Spain
}

\section{A R T I C L E I N F O}

\section{Article history:}

Received 4 January 2013

Received in revised form

28 February 2013

Accepted 1 March 2013

\section{Keywords:}

Arabia

Mangrove

Sabkha

Neolithic

Mid-Holocene climate

Shell middens

Sea-level highstand

\begin{abstract}
A B S T R A C T
This paper focus on the Holocene palaeogeography of the Ja'alan coast from the 6th to the 4th millennium cal. BC, integrating the dynamics of mangroves, lagoons, khors-estuaries and deltas, with sea-level change and the evidence from Neolithic shell middens. The distribution and maturation of mangrove ecosystems along the Arabian coasts has varied considerably, affected by physical forces such as sea-level changes, climate, tidal amplitude and duration as well as the quantity of fresh water inflow associated with the monsoon systems along the Arabian coast. Palaeo-mangroves and lagoons, today replaced by large sabkhas, appear to be correlated to mid-Holocene fossil deltas and estuaries that currently function episodically, depending on the rhythm of winter rains. All these parameters have determined and impacted the location of settlement networks and the economic strategies of the first Arabian farmers along the eastern Arabian coast. The mid-Holocene sea-level highstand stability (5th millennium BC) can be considered to be an optimum period for mangrove development and can be correlated with Neolithic sites around the mangroves. The decline of mangroves since 3000/2500 cal. BC and further degradation is mainly attributed to the prevailing arid climate that reduced summer monsoon effects in the tropical area by favouring the extension of sabkhas. We discuss these aspects based on new archaeological surveys, excavations and geoarchaeological studies.
\end{abstract}

Published by Elsevier Ltd.

\section{Introduction}

1.1. Mangroves - their characteristics and utility in palaeoenvironmental studies

The mangrove ecosystem (MGE) is associated with intertidal habitats in the tropical and subtropical regions between approximately $30^{\circ} \mathrm{N}$ and $30^{\circ} \mathrm{S}$. Numerous papers deal with the large tropical deltaic areas associated with the development of dense mangrove ecosystems that are living today, but particularly vulnerable because of climate and coastal changes as well as a recent rise in clearing projects (Florida, Caribbean, India, Africa, Australia, South Pacific, South America...) (Limaye and Kumaran, 2012). The mangrove-lagoon swamps and sediments deposited

\footnotetext{
* Corresponding author. Tel.: +33 (0)478773113.

E-mail addresses: Jean-Francois.Berger@univ-lyon2.fr, bergerguilbert@neuf.fr (J.F. Berger).
}

over time represent a product of past and recent interactions between the geosphere and the biosphere along tropical coastlines (Limaye and Kumaran, 2012). Their development is limited to areas with calm water, associated with gently sloping sedimentary intertidal zones and a relative stable sea level. Mangrove ecosystems maintain the quality of coastal waters, protect coastlines from erosion during storms, and represent a natural resource base for silviculture and a large range of economic products and also provide habitats for rare fauna (fish, shellfish and crustacean species) (Ellison and Stoddart, 1991). Therefore, as mangrove peats are associated with accumulation of plant detritus and high rates of organic production, they provide very good records of palaeoclimates and palaeoenvironments. Mangrove deposits have been widely used to study sea-level changes in tropical areas with a $\pm 1 \mathrm{~m}$ precision (Belperio, 1979; Ellison and Stoddart, 1991; Behling et al., 2004; Kumaran et al., 2005). Pollen studies in mangroves are frequently used to establish the history of MGE, but are still scarce in the region of study (Lézine et al., 2002). Their use is more developed along the Indian coast (Limaye and Kumaran, 2012). 
1.2. The context of Neolithic palaeo-mangroves and their disappearance in eastern Arabia

Geoarchaeological research conducted by the Joint Hadd Project (M. Tosi and S. Cleuziou dir.) since 2002 and the Ja'alan-Dhoffar French mission for the last two years (V. Charpentier dir.), has enabled us to characterize different sedimentary contexts along the eastern Arabian coast of Oman (in-site and off-site analysis). This has enabled us to investigate the interaction between Neolithic populations and their coastal environment from the 6th to the 4th millennium BC. There are few papers that discuss the dynamics of eastern Arabian coast mangroves, as they are today very scarce, but these ecosystems were very extensive and active from the end of the Early Holocene to the mid-Holocene during the period of maximum postglacial sea-level transgression and Arabian monsoon (AM). The presence of a powerful upwelling along the Ja'alan coast appears to have been important for their development. At the same time, archaeological discoveries raise important questions regarding the mid-Holocene population development in this part of the Middle East. Shell gathering took place in different periods according to the availability of the mangrove resources, as part of different cycles of prehistoric subsistence (Biagi, 2013). The Neolithic was a major period in this respect, and current research, based on important radiocarbon series, demonstrates that similar dates come from numerous shell middens distributed along the shores of the Arabian peninsula, the Persian Gulf, the Makran, Las Bela and Lower Sindh (Pakistan)(Uerpmann and Uerpmann, 2003; Méry et al., 2009; Biagi and Nisbet, 2006; Biagi, 2011, 2013; Desse and Desse-Berset, 2005). How may this regional historical tendency be explained? The environmental parameters discussed could explain the broad development of Neolithic shell middens, in a phase of optimal occupation of the coastal areas. In Arabia, mangrove development was generally related to sea-level oscillations and fresh water influx of the monsoon systems (M.S.) (Lézine et al., 2002; Berger et al., 2005). Along the Ja'alan coast, tectonic activity has played a supplementary local role since the mid-Holocene (subsidence activity).

The reason for the decrease of mangroves in this region is still debated, because in other major tropical areas mangrove expansion continued during the Late Holocene. Temperature stress at the latitudinal limits of mangroves cannot be responsible in the Arabian region, as MGE with Avicennia marina forests extend up to $27^{\circ} \mathrm{N}$. along the Red Sea coast and into the Persian Gulf up to $26^{\circ} 32 \mathrm{~N}$ (Woodroffe and Grindrod, 1991). When deceleration and relative stability of sea-level rise occurred for the 7 millennia, the Ja'alan coast always presented favourable intertidal habitats, with gently sloping shores. The changes in fresh water supply linked to the change of the monsoon regime represent perhaps the main limiting factor in eastern Arabia. The mid-Holocene abrupt climatic change, of orbital origin, that considerably reduced the activity of the Arabian rivers and the delta water supply due to a significant decline of the AM to the south (Fleitmann et al., 2007; Berger et al., 2012) must be considered (Lézine et al., 2010). Today, only the wadis with a large and higher watershed in the highest part of the Oman mountains (Jebel Akhdar, around $3000 \mathrm{~m}$ ) still provide water to small permanent mangroves in eastern Arabia (Qurm, Quriat, Filin) (Figs. 1 and 2A). The mangrove wetlands of the eastern coast of Arabia are small, and the typical vegetation often scarce or residual, as in the periphery of the Khor Jaramah lagoon in the northern part of the Ja'alan region where a bank of Avicennia sp. is still visible. They have been replaced by large sabkhas (Fig. 3), which represent today large coastal saline depressions, episodically supplied with fresh water by rainy winters, like the one in $2011 / 2012$.

As the proxy data indicators of past mangroves, coastal lagoons and sabkhas are directly impacted by climatic, geomorphic, eustatic and geological changes, and may reveal not only the past extent of

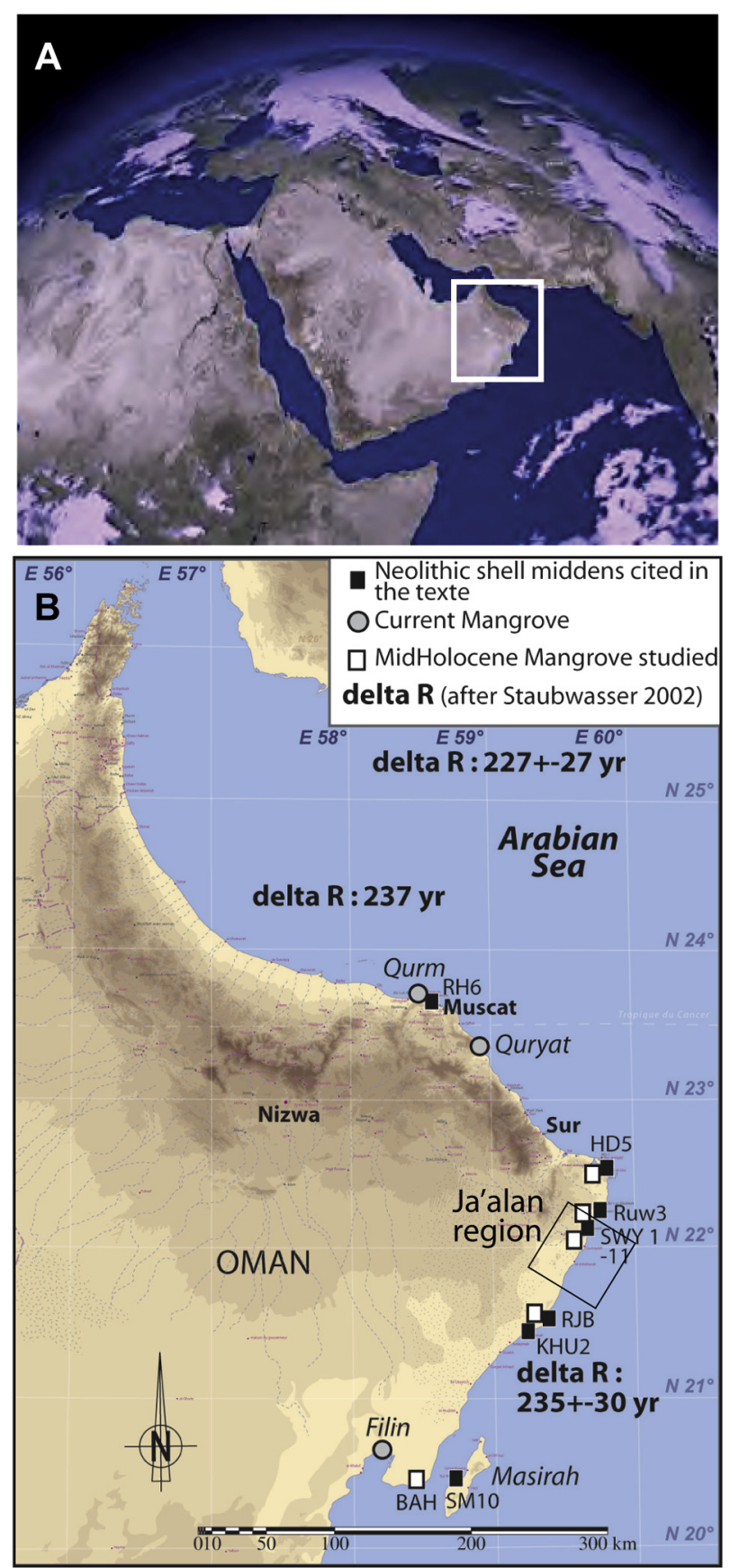

Fig. 1. A/Location of Oman and the Ja'alan region, B/Regional map of Eastern Arabia with the main archaeological sites attesting a mangrove exploitation during the Neolithic period. The delta Reservoir (dR) of the seas in the Arabian Sea and Persian Gulf are mentioned.

mangroves but also changes in the coastal environmental conditions, that have sometimes impacted the regional settlement systems. The rise of the average sea level has an immediate and direct effect on ecosystems of the intertidal zone (Ellison and Stoddart, 1991). Archaeological survey and excavation conducted around these fossil ecosystems highlight not only the proximity of the locations of Neolithic sites and their economic attractiveness for past societies, but also their availability during climatic stress periods (Biagi and Nisbet, 2006).

The Arabian Sea mangroves can be considered to have been highly productive in many ways for the prehistoric subsistence economies. The high organic content of the mangrove mud 


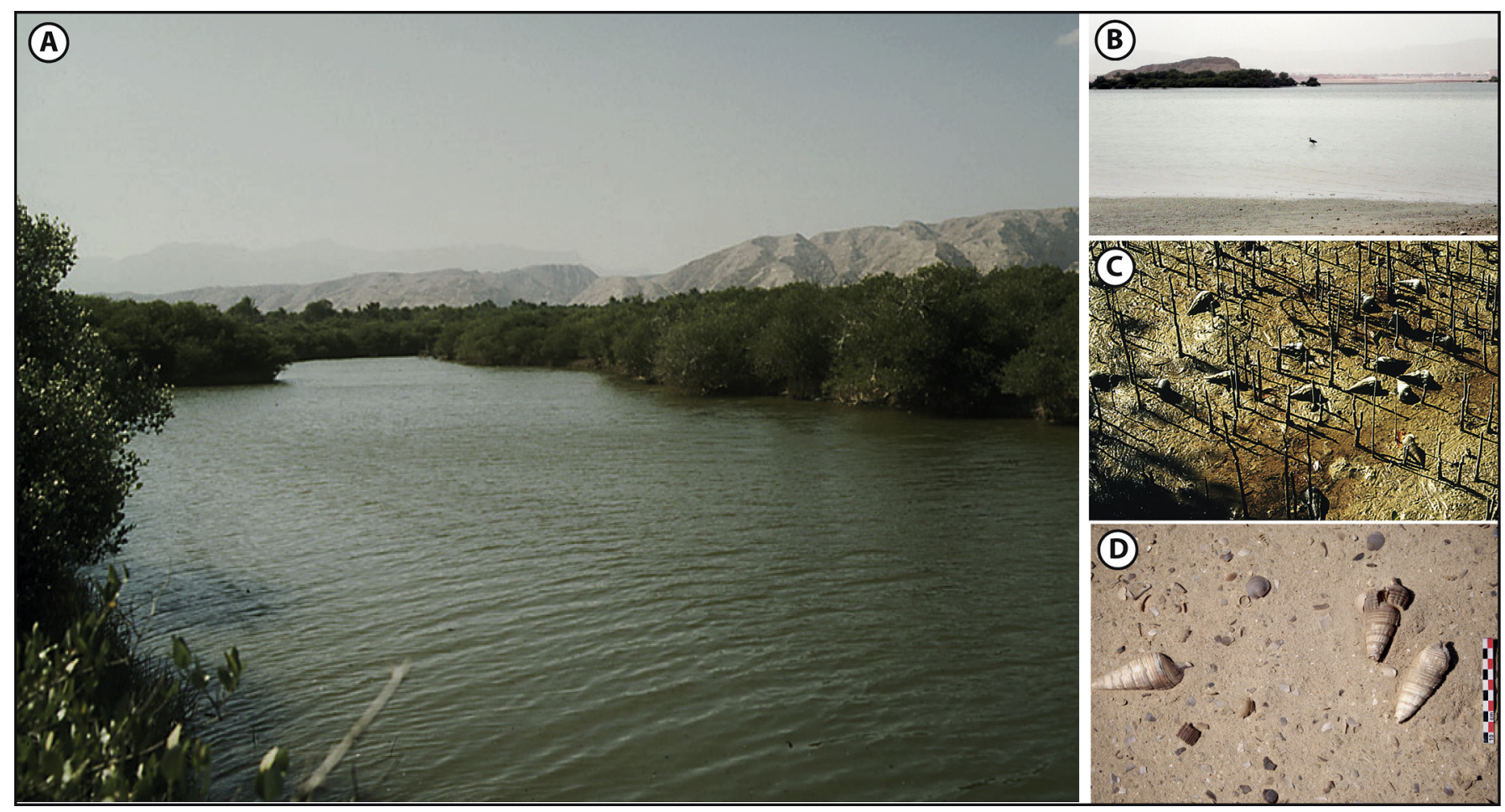

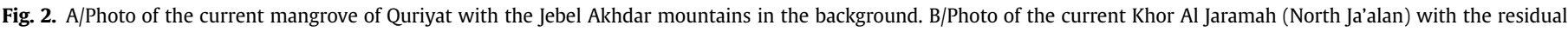

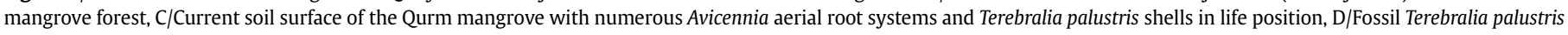
shells on the current surface of a mid-Holocene dead mangrove in the Bar Al-Hikman delta.

constitutes the basis of a food chain that includes important staples, among which are oysters and other molluscs, in particular the gastropod Terebralia palustris (Fig. 2b,c), as well as fish, crabs and birds (Chapman, 1976; Hutchings and Recher, 1983; Martin, 2005). Since palaeoenvironmental studies have been developed in archaeology, numerous ecofact data demonstrate the use of mangroves. Mangrove trees were considered to be important for construction, for charcoal-making and for fuel. Along the Arabian coast, numerous coastal on-site Neolithic charcoal assemblages are an indication of the pre- to protohistoric exploitation of mangrove ecosystems by past Arabian societies (Biagi and Nisbet, 1992, 2006; Tengberg, 2005). Malacology studies of shell midden sediments complete this information and enable understanding of the coastal strategy of the first Neolithic populations of the Ja'alan in these lagoon and mangrove environments (Martin, 2005). A quick comparison with the northern Arabian coast (Pakistan) settlement dynamic shows that we are dealing with a large regional human phenomenon that affected thousands of kilometres of coasts, which we intend to analyse from a socio-environmental perspective. No regional synthesis concerning the dynamics of diachronic mangrove ecosystems has been made for the Arabian seacoasts, mainly because of the lack of coastal geological data. We propose the first spatio-temporal reference framework based on the latest interdisciplinary data collected along the eastern coast of Oman, and discuss the chronology of the appearance of regional sabkhas.

\section{Material and methods}

2.1. An integrated and combined off-site and in-site geoarchaeological and palaeoenvironmental approach

\subsubsection{Landscape studies}

Photo-interpretation and data analysis based on satellite images are first used to distinguish different geomorphic units on the coastal plain and to pose hypotheses on the locations of old lagoons, mangroves and palaeochannels (Fig. 4). Secondly, they enable, in complex deltas and estuaries systems, sequencing of the deltaic sedimentary progradation and mapping of their different morphologic components (channels, estuaries, lagoons/mangroves, shorelines...) and their recent evolution (sabkha development, marine erosion, dune invasion, lateral redistribution by streams...). The first stage of the coastal geomorphological study was also made in the Ja'alan region (Berger et al., 2005) and was subsequently supplemented by further analysis in others areas such as the Khuwaymah bay and the Bar Al Hikman delta, in the southern part of the Wahiba Sands (Charpentier et al., 2012a). The main Holocene sea-level variations were presented and discussed on a regional scale in the same paper (Berger et al., 2005), and are integrated in the landscape reconstructions of the coastal evolution.

\subsubsection{The in-site studies and their significance}

Past coastal landscapes and their spatial organization may also be interpreted from the ecofacts (charcoal, shells, micro-fauna such as crabs, waterlogged wood...) accumulated on the Neolithic shell middens and in off-site contexts such as palaeo-lagoon and peaty mangrove units (Martin, 2005; Biagi and Nisbet, 1992, 2006; Tengberg, 2005). The use of the pedosedimentary archives that constitute shell middens through geoarchaeological tools is also appropriate to detect past climatic changes and anthropogenic sedimentation (Charpentier et al., 2012a). Shell midden sequences in the region contain direct fluvial signatures when they are located on older alluvial formations, or they contain paedogenic signatures of the weathering substrate or sedimentary formations (as on the site of Suwayh 1, forthcoming). All the archaeological sequences studied show a general development of sandy signatures in their upper part, with typical eolian features (oblic laminations, ripplemarks, micro-dunes, deflation pockets, gypsum accumulations) 

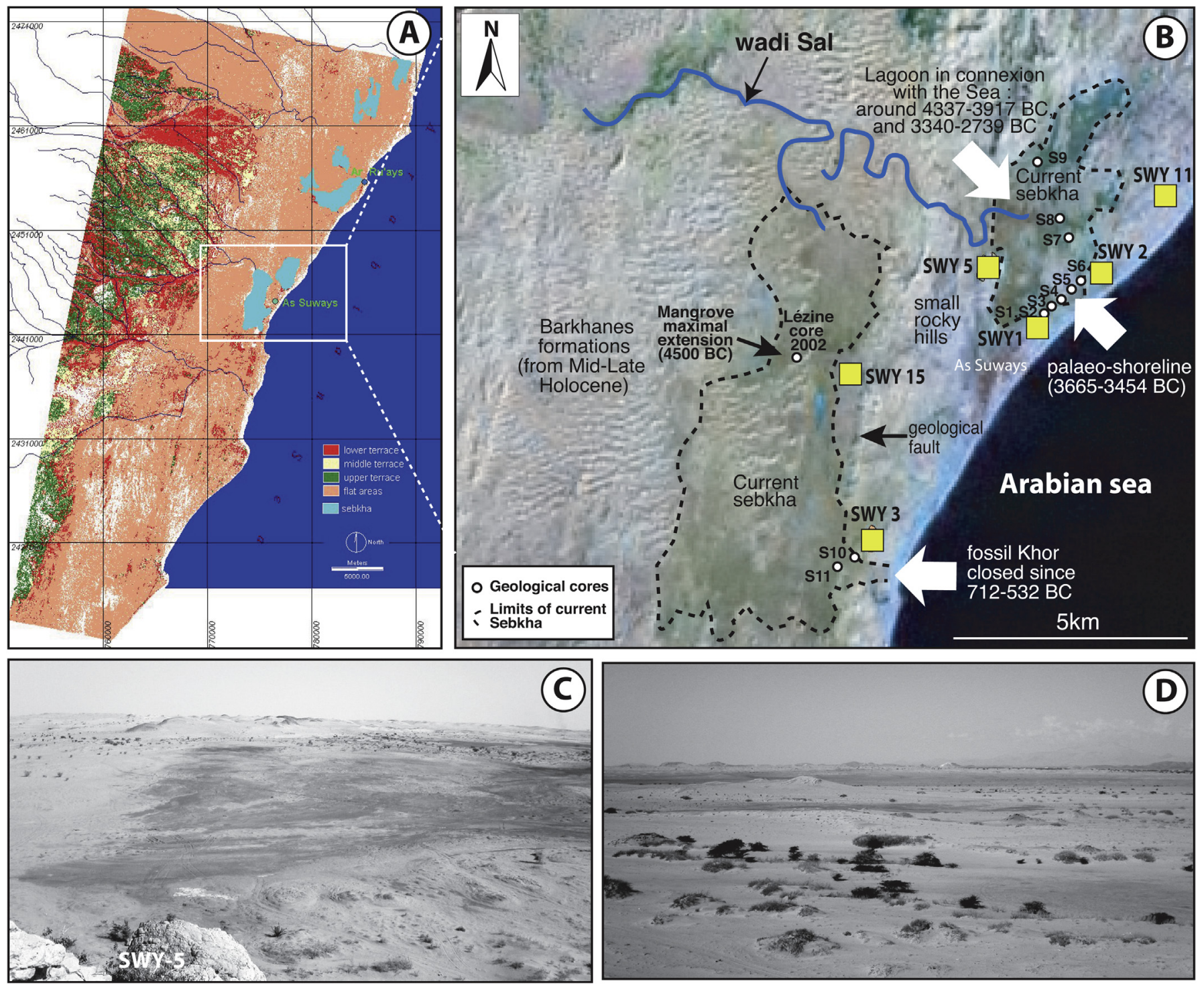

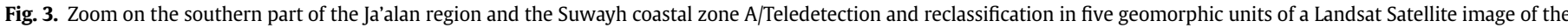

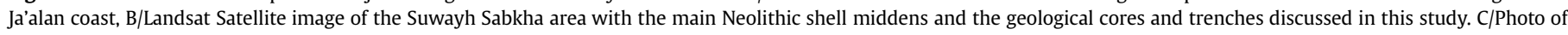

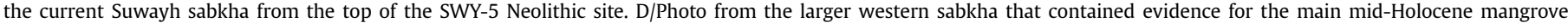
expansion at $5 \mathrm{~km}$ from the current coastal zone.

that have partly removed the anthropogenic formations and are evidence of climato-environmental changes.

\subsubsection{Field and laboratory methods}

We use here both direct (coring and excavation) and indirect data (from archaeological sites) to explore the past dynamics of mangroves and sea-level changes and their impact on settlement networks along the Arabian coast. Cores (manual Edelman-corer) and mechanical trenches, 3-4 m deep, undertaken after photointerpretation study, were also directly applied to the sedimentary formations of the Ja'alan coast, mainly in the current sabkhas which contain deep pedosedimentary archives (Figs. 1, 3 and 4). Lithofacies are classified in the field by their colour, grain size, organic debris composition (wood fragments and micro-remains) and macro-benthic fauna to distinguish their sedimentary environment and the palaeodynamic responsible for their deposition. Additional sedimentological analyses were carried out in the OMEAA laboratory in Lyon 2 University. Grain size analysis by laser coulter was carried out to record the conditions of deposit, and magnetic susceptibility measures by MS2E Bartington sensor to discriminate the sedimentary sources (versus biogenic local or nonlocal allogenic eolian dust or sand). Organic carbon analysis was performed by loss on ignition (LOI) after the Bell method (1964).

The shell material from in-site and off-site sequences was identified at the Laboratory of the Biology of Marine Invertebrates collection at the Muséum National d'Histoire Naturelle in Paris and with the help of several specialized books (Oliver, 1992; Bosch et al., 1995). In the excavation of Suwayh 1, 28 archaeological levels have been studied from $4 \mathrm{~m}^{2}$ and $2 \mathrm{~m}$ deep. One hundred species were identified and divided into three classes: bivalves, gastropods and crustaceans (Balanus sp.). All the sediments have been dried and sieved with a $4 \mathrm{~mm}$ mesh (approximately). The sieve residues were then sorted to obtain all the small shell fragments. A minimum number of 16,935 individuals (MNI of frequency) have been counted for 27,671 remains.

The species of mollusk identified in the archaeological context are very different from the present-day species, as several species no longer exist in the sea of Oman. Of all the species represented on 


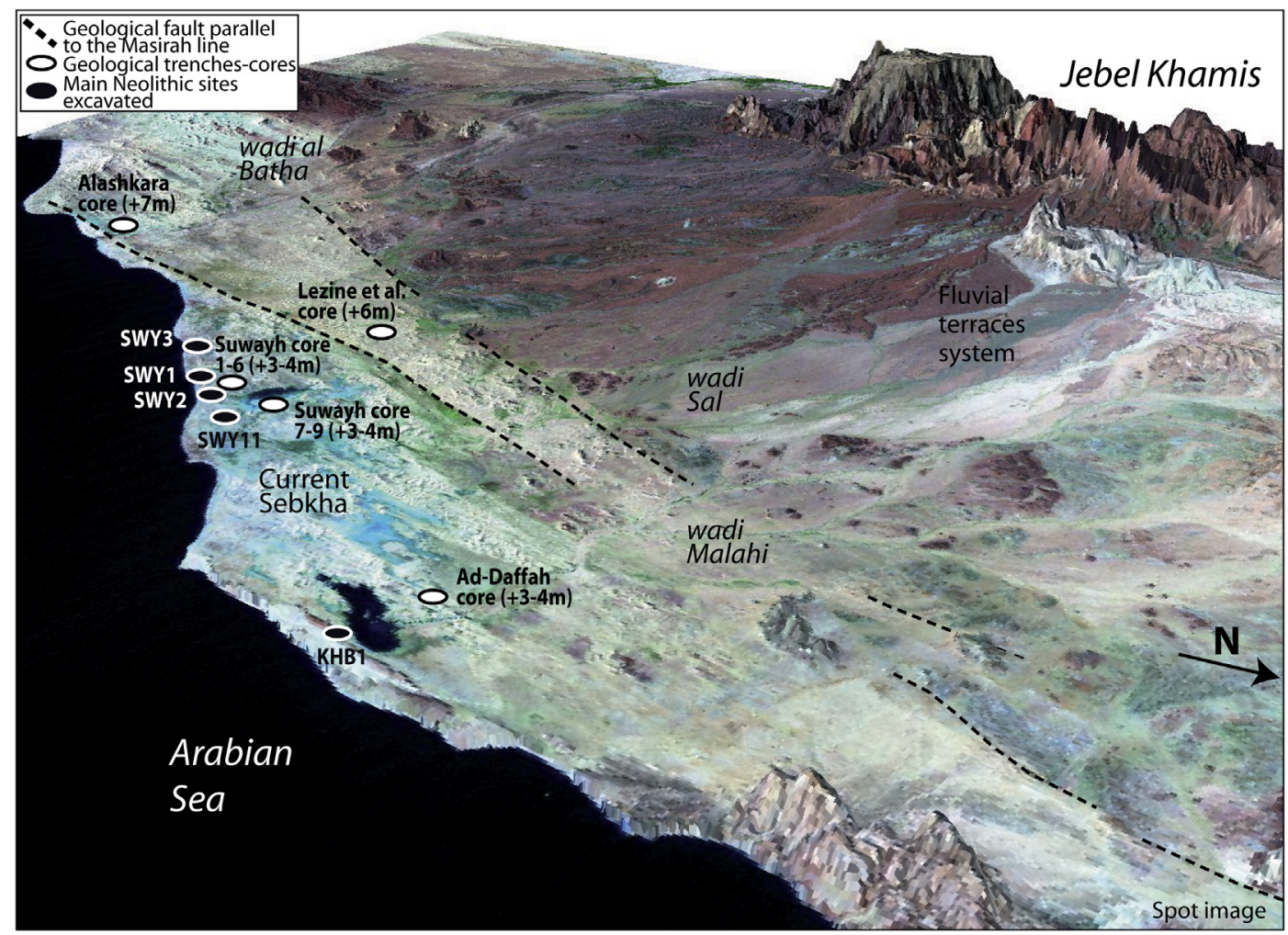

Fig. 4. 3D view of Ja'alan from the NE with main geological cores and the geological faults that explain partly the high topographic level of the current coastal plain.

the site, a bivalve of the genus Meretrix is unidentified and could represent a new species (Martin and Matsukuma, 2006).

\subsubsection{Chronology: in-site and off-site, and regional tendencies from a relative probability plot}

Radiocarbon dating was carried out as soon as possible on charcoals, to avoid the reservoir effects on shells that occur during the Holocene period. But many ${ }^{14} \mathrm{C}$ dates compiled in the literature in the eighties came from shells in natural contexts, those from diverse environments often being the only samples that can be dated. To discuss the presence of MGE around shell middens, we selected radiocarbon dates made on T. palustris and Telescopium telescopium species and added the active marine delta reservoir data according to their geographical position. The ${ }^{14} \mathrm{C}$ marine delta reservoirs in the Arabian Sea and the Persian Gulf are indicated on the regional map (Fig. 1). Based on recent measurements of the marine reservoir effect in the Arabian Sea, ranging from today to 8685 cal. BC, it is possible to discuss the ${ }^{14} \mathrm{C}$ calibration of marine biomineralisations. During the Early to mid-Holocene, the high amplitude in sea surface temperature variation linked to intensified upwelling activity led to higher values for the marine reservoir effect. We apply the results of Staubwasser et al. (2002), Dutta et al. (2001) and Saliège et al. (2005) to calibrate the Holocene shell datings of in-site and off-sites contexts of the Oman and Pakistan coasts (Arabian Sea). The Delta $\mathrm{R}$ dates to 425 years prior to 5500 cal. BC, to $227 \pm 27 \mathrm{yr}$ after that date along the Pakistan coast and to $235 \pm 30 \mathrm{yr}$ along the Oman coast. Radiocarbon dates were calibrated using the Oxcal Program (Bronk Ramsey et al., 2002).

\subsubsection{Archaeology, cultural and micro-regional evolution of settlement systems}

We complete the palaeogeographic study of the Neolithic coast by an analysis of the settlement system along the Arabian coast of
Ja'alan, which was intensively surveyed over 25 years. More than 50 Neolithic sites were discovered between Ra's al-Jinz and Aseelah and at least 5 shell middens were partly excavated, mainly in the Suwayh area (Charpentier et al., 2000, 2003, 2012a; Mery and Marquis, 1999). All the sites make up a database that were projected on the palaeogeographic maps using GIS. This integration of data demonstrates that shell middens are not located haphazardly along the Oman coast. Topographic, hydrological and physiographic parameters explain most of the settlements of the Neolithic period.

The last 25 years have yielded a ground-breaking amount of data on coastal Neolithic occupations. The archaeological sites (e.g. Suwayh, Ra's al-Hamra, Khuwwaymah), mostly shell midden sites are usually rich in homogeneous cultural material characterized by a wide range of fishing equipment, such as mother-of-pearl shellhooks (Charpentier and Méry, 1997), and net-sinkers or lineweights made of stone or sea shell (e.g. Charpentier et al., 2012b). Anthropic activities are also illustrated by ornaments (de Beauclaire et al., 2006; Charpentier et al., 2012b), funerary practices (e.g. Uerpmann et al., 2006; Uerpmann and Uerpmann, 2009) and ritual structures (Méry et al., 2009), as well as objects such as different types of scrapers made from shells (Charpentier et al., 2004), and diverse tools made from marine animal bones (Charpentier et al., 2009). Finally, the lithic industries are an important aspect of the archaeological record, illustrated by projectile points (including the "trihedral" and "fluted" points), and many types of tools made from various local raw materials (e.g. Charpentier, 2004, 2008; Uerpmann et al., 2009). Throughout the period, from the 6th to the 4th millennium cal. BC, there is a clear cultural homogeneity in the coastal occupations that reflects a distinct tradition common to the entire Oman Peninsula, with proven links with the broader southern Arabian peninsula, and possibly beyond to the north (Biagi, 2005). Thanks to a 
collaborative approach to the analyses carried out these last years, paleoenvironmental and archaeological studies have enabled a quite detailed, but still fragmentary, picture of the socioeconomic situation for these communities (Lézine et al., 2002; Uerpmann and Uerpmann, 2003; Berger et al., 2005; Parker and Preston, 2008; Charpentier et al., 2012b, in press). They are considered to have been Neolithicized human groups, but possibly not in a "classic" sense as they were not fully dependent on a production economy. Indeed, agriculture is not in evidence for this period and herding was probably a marginal activity for these fishermen communities. Other aspects, such as a specific seasonal occupational pattern (e.g. Uerpmann et al., 2012) and a certain degree of nomadism, long-distance trade, and partial sedentarism, are keys to a social definition that continues to need in-depth studies (Cleuziou, 2004; Crassard and Drechsler, 2013).

\subsection{The region of study}

Archaeological and palaeoenvironmental data are located between the 24th and the 20th northern parallel, from Muscat to the Bar Al-Hikman palaeodelta in the southern part of the Wahiba Sands (Fig. 1). Located in the eastern part of the great Arabian desert of Rub'al-Khali, the Ja'alan region receives an average annual rainfall of $50 \mathrm{~mm}$. The climate is arid. Since the mid-Holocene, summer monsoon rains have been blocked by the north-western flows that convey warm and dry air. Only winter rains reach this area, due to the penetration of eastern Mediterranean troughs in the Persian Gulf following the Zagros topographical barrier. Eolian processes have predominated for the last four millennia (Cullen et al., 2000). These explain the strong dune development in the coastal plain and the invasion of wadi beds and sabkhas by barchan formations which have occurred since the second part of the midHolocene (Berger et al., 2005) (Fig. 3). These climatic conditions explain why the sparse regional vegetation is semi-desert (Lézine et al., 2002). They promote the precipitation of gypsum in soils. The main coastal wadis (Sal, Massawa and Al Batha) appear to be very ephemeral today, with an upper watershed under $1000 \mathrm{~m}$, but the relictual Early/mid-Holocene alluvial formations are evidence of their powerful activity in the past.

In Fig. 1, the few present-day mangroves appear in grey circles. They are still supplied today by large wadis (such as the Wadi Andam in the western part of the Wahiba Sands, the Wadi Aday near Muscat, the Wadi Hawir in Quriyat). The current large sabkhas of the Ja'alan that have been geologically explored appear in white squares.

Figs. 3 and 4 (3D view from the north of the southern Ja'alan), show the exact location of the geoarchaeological survey as well as the coring and mechanical trench-digging carried out in the large sabkhas of the southern Ja'alan (in black circles). They enable us to record the palaeogeography and the palaeoenvironments of this coastal area. They provide information on the sea-level fluctuations, the occurrence and the chronology of old khors, lagoons and mangroves, their disappearance and their replacement by clayey sabkhas with gypsum crusts, more or less invaded by barchan dunes during the mid/Late Holocene. Tectonic activity has locally disturbed the absolute elevation of the sites under study, as indicated by the main faults identified in the centre of the satellite image, drawn in black dashes (Fig. 4). They are parallel to the main regional marine fault called "Masirah Line" (Berger et al., 2005). They have from time to time amplified the high sea-level records in the Ja'alan. For this reason, the Ja'alan data for sea-level change cannot be used as a local reference, but the main tendencies observed correspond to the regional data of the Arabian Sea and the Persian Gulf (Berger et al., 2005; Sanlaville and Dalongeville, 2005).

\section{Results and interpretation}

\subsection{Main geological and environmental data of the Suwayr and Alashkara sabkhas}

The main data corresponding to the palaeogeography and sealevel changes of the Suwayh zone have been published in a previous paper (Berger et al., 2005). The geological data located in the sabkha up to the sandbar present at least five sea-level transgressions (middle of the 5th mill. BC, around 3700-3600 BC, end of the 4th mill., around 2700-2600 BC and 2400-2200 BC) (Figs. 3A and $5 \mathrm{~A}$ ). These results are in agreement with the older regional data in Oman, which are often occasional (Berger et al., 2005). Several phases of MGE development are identified on the basis of pedosedimentary and malacological data (Martin, 2005), to between 4300 and 4000 and a little after 3650-3450 BC (Fig. 5A). The maximum extension of the mangrove forest appears in the Ja'alan around 4150 BC, up to several kilometres inland in the coastal plain (Martin, 2005; Lézine et al., 2002). Favourable topographic and environmental conditions such as gently sloping intertidal areas explain this situation locally. The lower khor to lagoon facies (Figs. 6 and 1A/B) are associated with high content of thin sands, more or less rich in shells, with very low values of magnetic susceptibility (bioclastic sand contributions mainly coming from the Arabian Sea and the south-eastern beaches). The transition to a sabkha environment occurred just after 3358-2774 BC in the small sabkha north of Suwayh (T7-T7, Fig. 6). The last lagoon clay facies containing lagoon shell species (around $-0.9 \mathrm{~m}$ deep) is covered by laminated redbrown clay bands, alternating with yellow to beige eolian sands. A hyper-arid phase characterizes this non-dated late Holocene facies (3a) marked by a high content in coarse sands, very little organic matter, and very high values of magnetic susceptibility (between 30 and $80 \mathrm{Si}$ ), which indicate a change in sediment sources. We presume that eolian sediment inputs are here allochthonous, and are probably transported by dominant north-western winds from the Oman hinterland rich in ophiolites and basaltic rocks. The upper sediments (3b) show a decrease in allochthonous sands, a higher content in clay and silt, and are rich in organic matter. These horizons characterize a less arid climate, with sabkhas functioning more often as seasonal lagoons. No chronological indicator could be used to date this last hydrological change.

In the Al-Ashkara trench, located in the wadi Al-Batha deltaic zone, the wood assemblage studied and the associated lithic material demonstrate the continuous development of a local mangrove peat ecosystem, over more than half a metre, dating from at least $5400 \mathrm{cal}$. BC to $4300 \mathrm{cal}$. BC. This follows a fine laminated lagoon facies whose bottom was not reached by the manual corer (Fig. 5A). This sequence shows the abrupt transition to a lagoon open to the sea associated with a coarse marine sedimentation that locally eroded the top of the MGE unit, and that is permanently associated with lagoon shell assemblages, more or less in connection with the sea. The transition to a sabkha environment occurred after 3003-2775 cal. BC and before 2132-1880 BC, based on shell dating, a date that corresponds to a new sea-level rise in the $\mathrm{Al}-$ Ashkara area that eroded the first sabkha deposits. Geophysical, micromorphological, palynological and biomarkers analyses of this mangrove/lagoon sequence are still in progress.

\subsection{Evidence of fluvial records on regional shell middens (6th to 5th millennium)}

The use of relict fluvial formations dated to the early and mid-Holocene, identified under some shell middens, provides information on periods of activity and progradation of coastal deltas. 


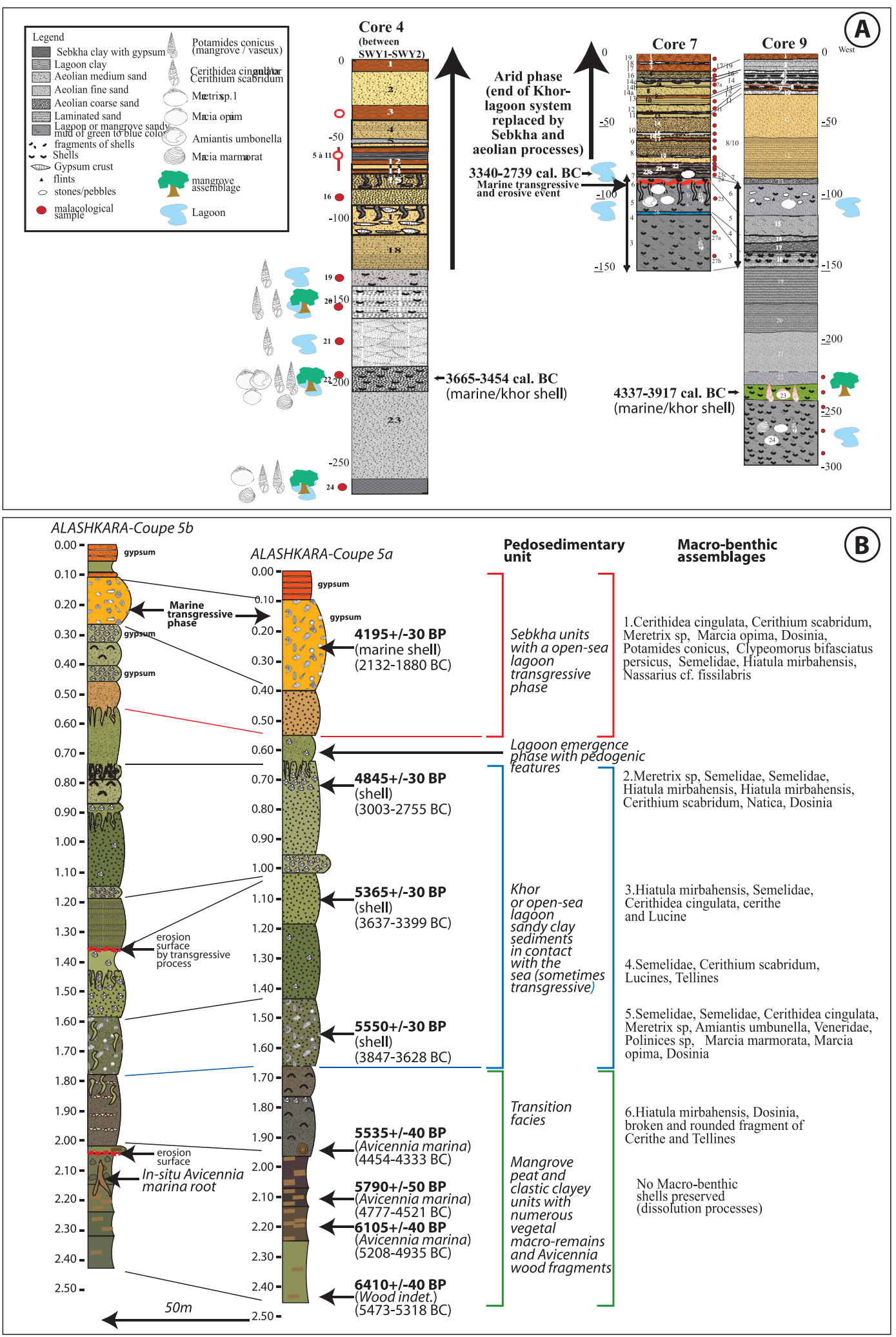

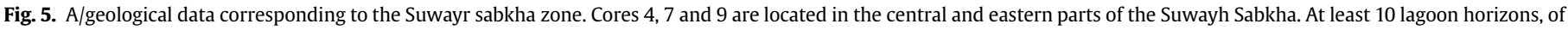

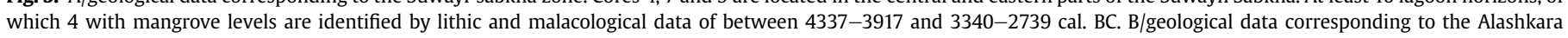

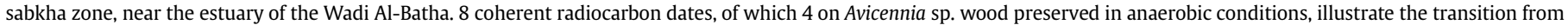
a mangrove peaty level to a lagoon open to the sea and a sabkha environment. 


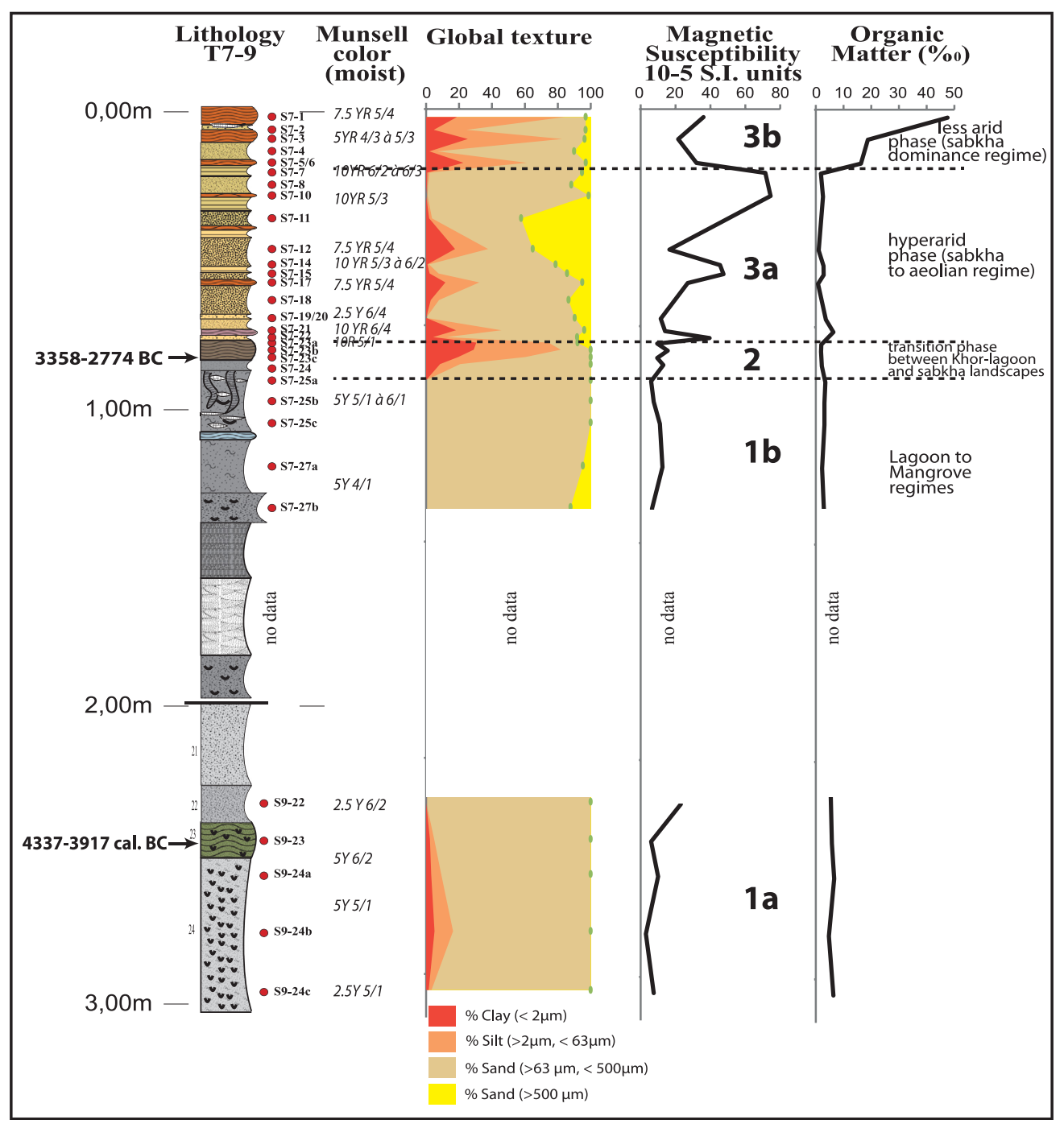

Fig. 6. Pedosedimentary and geophysical characteristics of trenches 7 and 9 of Suwayh sabkha with main environmental phases.

They illustrate the humid Holocene period (8500-4000 BC) when the Arabian M.S. was more to the north.

The site of Ruwais 1, recently degraded by bulldozers, provides more than $50 \mathrm{~m}$ of shell midden stratigraphy (Fig. 7A). We can observe a similar dynamic in Suwayh 11: the formation of a thick fluvio-deltaic sequence with large shallow channels. They indicate a strong lateral mobility in which the first Neolithic sites are interbedded between flood deposits. These sites have been dated to at least the beginning of the 5th millennium BC by archaeological objects (radiocarbon dates are in process). After the 5th mill. BC, we observe the appearance of sandy eolian formations that buried and partly disturbed the upper levels of the 5th mill. BC and strongly eroded the 4 th millennium levels by laterally redistributing a part of the site.

On the Neolithic site of Suwayh 11 (Fig. 7B, Charpentier et al., 2000), the formation of a gravelly and sandy terrace is observed for the transition between the Early to mid-Holocene, in the second part of the 6th millennium BC based on the first Neolithic artefact identified in the upper part of this fluvial sequence. Its formation partially removed the first Neolithic occupation levels.

The site of Ra's Dah SM-10, on the western coast of Masirah Island also shows similar fluvial signatures with a very active deltaic environment during the end of the Early Holocene, as shown by the identification of the mangrove species Rhizophora mucronata in the bottom layers of the site (by M. Tengberg, MNHN Paris). The first stratigraphic units of the shell middens are characterized by anthropic levels and levels eroded by strong water flows that mobilized sand and ballast (Fig. 7C). The absolute chronology places this period of abundant hydrology to between the first part of the 6th millennium and the 5th millennium BC (Charpentier et al., in press).

The very large delta of the Bar Al-Hikman, located south of the Wahiba Sands, drains the watershed of Wadi Andam which measures some tens of thousands of square kilometres (Fig. 7D). The first results of the geoarchaeological survey indicate a phase of fast progradation between the maximum period of transgression dated to the second half of the 6th millennium BC and the end of the 5th millennium $\mathrm{BC}$, where we observe a considerable drying-out of the mangrove around 4200 cal. BC (Charpentier et al., 2012a). Numerous shells of $T$. palustris were observed on a surface area of several dozen hectares during a field survey. From this date, the main part of the delta develops definitively into a dead landscape with no flooding aggradation because of a major fluvial avulsion that moved the Wadi Andam estuary to the current deep bay of Filin, more than $30 \mathrm{~km}$ to the west. The Bar Al-Hikman deltaic formations were then eroded and partly redistributed by coastal marine streams and wave energy. The sedimentation processes were slow during the Late Holocene period because of a strong slowing of sedimentary inputs. 

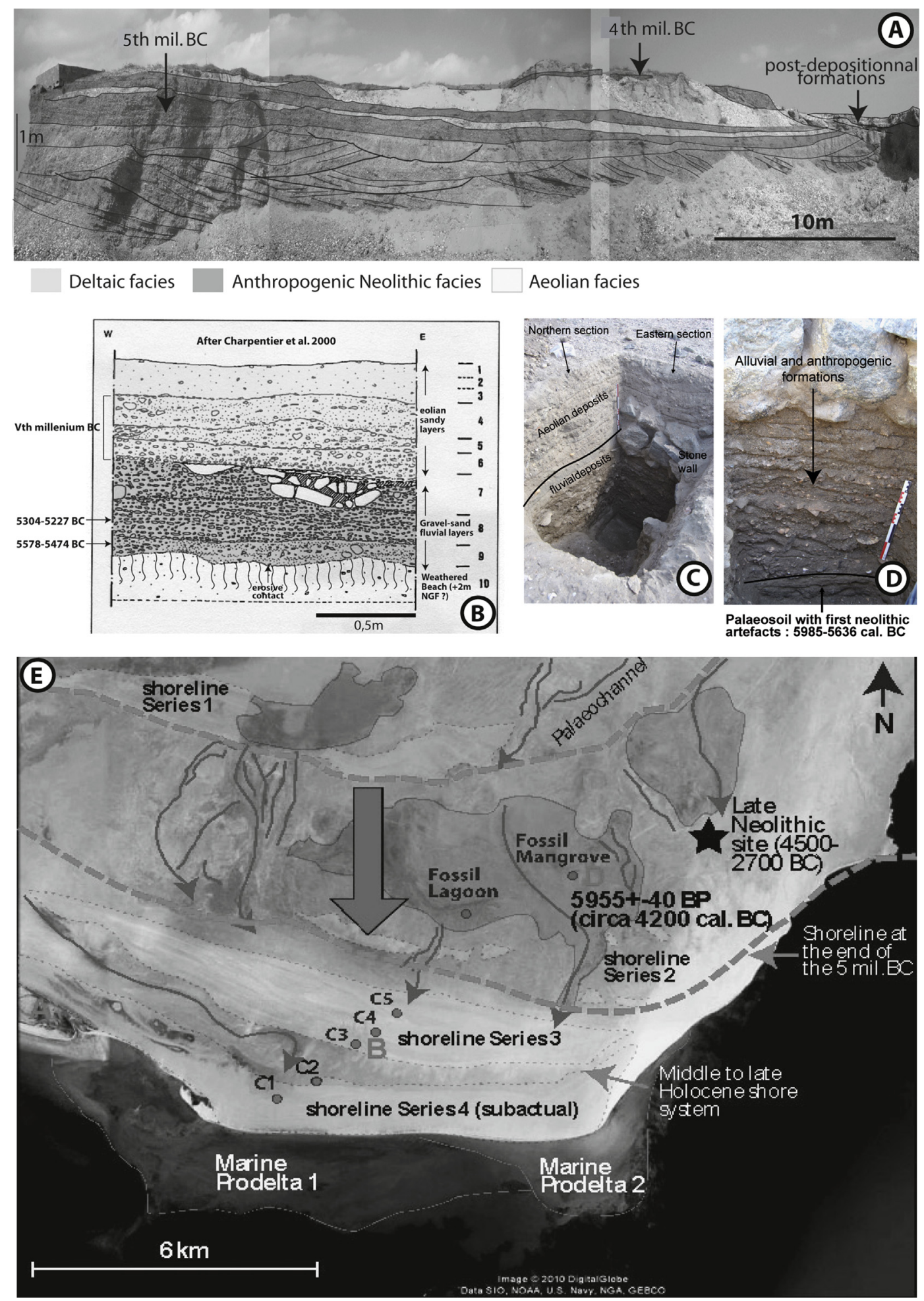

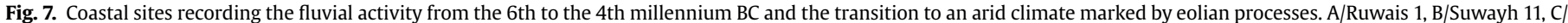
Sur Masirah 10, D/Bar al Hikman.

3.3. The chronology of the mangroves and open lagoons by the sea between Ja'alan and the region of Muscat (Oman), in the Indus delta and the coast of Las Bela (Pakistan)

The use of radiocarbon dating of in-site T. palustris shells and Avicennia sp. charcoal from Neolithic sites from Muscat to the
Ja'alan coast and from the coring of large sabkha systems enable us to investigate the chronology of mangroves and open lagoons by the sea over three millennia (Fig. 8). Most of the in-site data are concentrated in a plurisecular period (4700-4400 cal. BC). More to the north, the radiocarbon dating of 27 mangrove shell samples ( $T$. palustris and T. telescopium) link the prehistoric settlement of the 


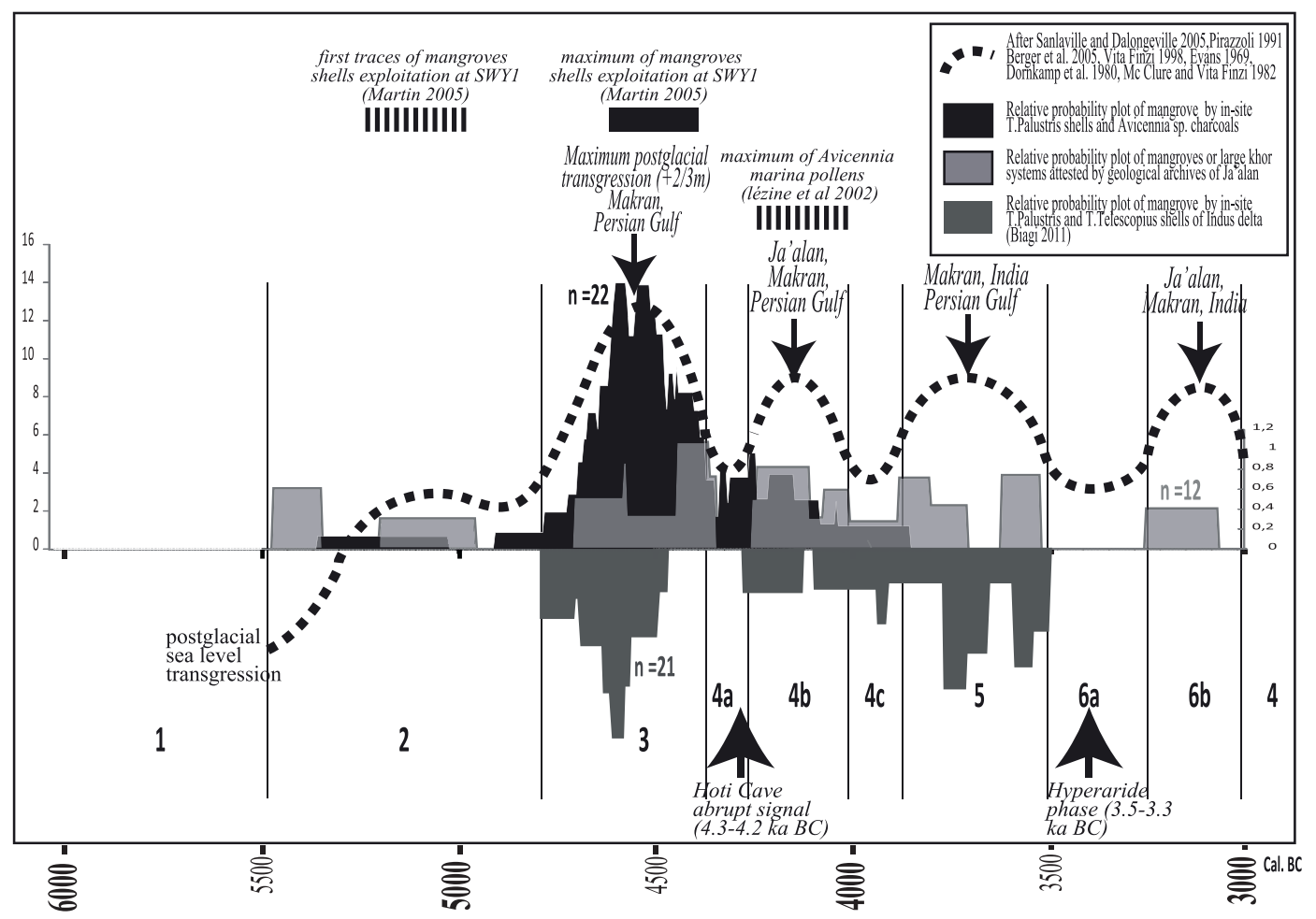

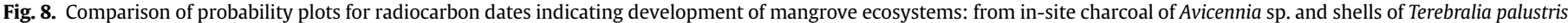

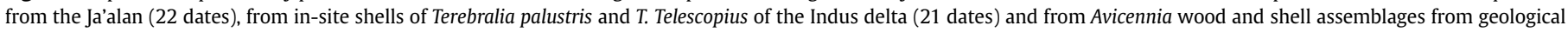

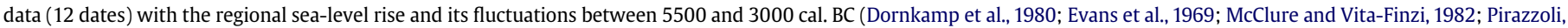
1991; Vita-Finzi, 1998).

coast of Las Bela (Baluchistan) and the Indus delta (Pakistan) with mangrove development (Biagi, 2011, 2013). Their relative probability plot illustrates two main periods of Neolithic occupation and active exploitation of mangrove ecosystems in the first part of the 5th millennium and the 4th millennium BC (Fig. 8). These absolute chronological series of data are correlated with data on regional sea-level changes to present a diagram illustrating seven phases between 6000 and 2000 cal. BC.

\subsubsection{Phase 1 (Early Holocene phase before 5500 cal. BC)}

There is a lack of data on the Neolithic sites and the geological archives studied. The reason is mainly eustatic and postdepositional. The sudden increase of the sea level during the Early Holocene (meltpulse 1b) makes it difficult to identify sites and geological formations which are buried under metres of water or have been destroyed by the marine transgression. The marine transgression occurs so quickly that mangrove ecosystems cannot adapt and thus disappear (Ellison and Stoddart, 1991).

\subsubsection{Phase $2(5500-4800 \mathrm{cal} . \mathrm{BC})$}

The sea level and the coastal landscapes are similar to those today. The sea-level rise slows down. The base level of the rare older shell middens (Suwayh 1) and the cores studied (Al-Ashkara), deeper than $3 \mathrm{~m}$, show the occurrence of palaeo-mangroves around the Neolithic sites in 5400 BC (Figs. 5B and 8). Occupation and exploitation of the eastern Oman coast appear to be still limited or partly buried by coastal sedimentation, thus not detectable by field surveys.

\subsubsection{Phase 3 (4800-4400 cal. BC): Optimum of mangrove development around the Arabian Sea}

Radiocarbon dating of in-site T. palustris shells and Avicennia sp. charcoals from Muscat to the Ja'alan coast and from large khor systems shows a maximal development of mangrove ecosystems along the eastern coast of Arabia and their extensive exploitation by Neolithic populations ( $T$. palustris shells, ubiquitous species such as Ostrea, nerita and Littoraria intermedia, Avicennia, wood for fire and building shelters, widely used during the 5th millennium BC).

On the Neolithic site of Suwayh 1, the period between 4700 and $4400 \mathrm{cal}$. BC corresponds to the maximal use of the nearby mangrove by the Neolithic groups and to an increasing diversity of the collected shell species (Martin, 2005) (Fig. 9). The in-site charcoal and pollen analyses (Tengberg and López-Sáez, oral communication) confirm the local development of an Avicennia and Rhizophora mangrove from 5400 to $4300 \mathrm{BC}$, based on the radiocarbon dating of 5 marine shells sampled from the centre of the shell middens (Table 1 ). The recovery of numerous postholes from circular houses and the frequency of hearths and ashy sedimentary units with numerous small Avicennia sp. charcoals (Charpentier et al., 2003) are evidence of an active exploitation of the Suwayh mangrove forests for more than a millennium. More to the north, the period 4600-4400 cal. BC still corresponds to a predominant presence of mangrove wood charcoals in the shell middens of Ra's al-Hamra 5 and 6 in the Muscat region (Biagi and Nisbet, 1992; Tengberg, 2005). Based on the frequency cumulative curve of radiocarbon dating of insite $T$. palustris and $T$. telescopium shells from the recently surveyed coast of Las Bela (Baluchistan) and the Indus river delta (Pakistan) (Biagi, 2011, 2013), a synchronous maximal peak of mangrove development has been identified (from 4800 to 4500 cal. BC). Numerous Neolithic shell middens were then occupied in the areas surrounding the bay of Daun, the lake of Siranda and the Tharro and Makli Hills in the Indus river delta (Biagi, 2011, 2013). It is during this chronological interval that the maximum postglacial sea transgression $(+2 / 3 \mathrm{~m})$ is 


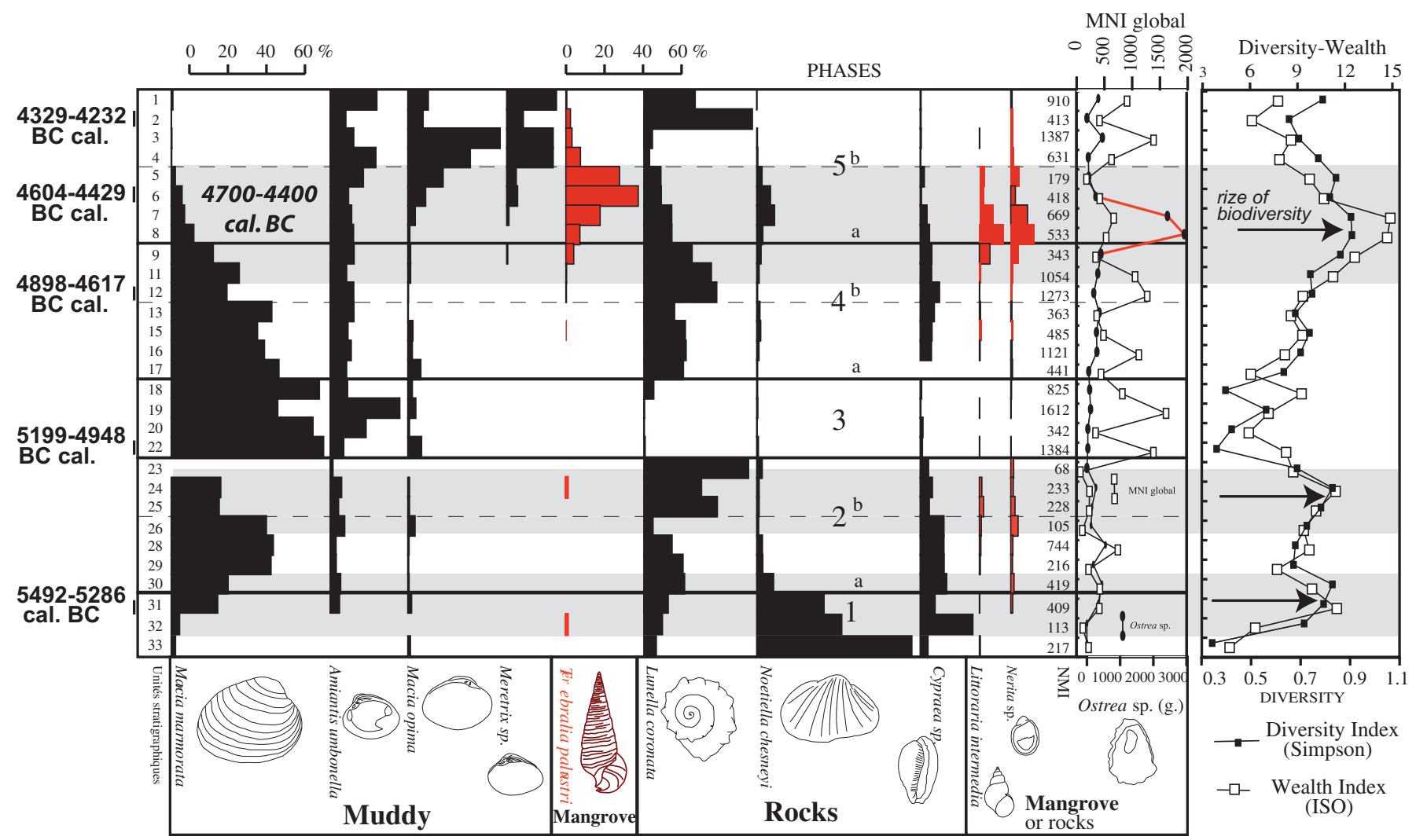

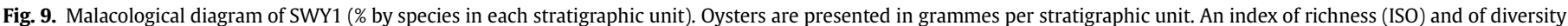

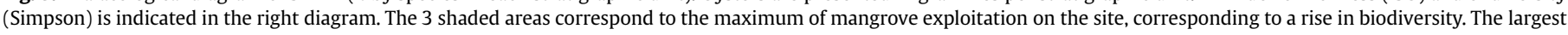
appear between 4700 and $4400 \mathrm{cal}$. BC (modified after Martin, 2005).

indicated in Ja'alan, Makran and the Persian Gulf according to regional data (Fig. 8). This period also corresponds to the second humid phase of the Holocene in the Arabian peninsula (Fig. 10). These eustatic (maximal stabilization of the sea level) and favourable climatic conditions (strong rain flow for the Arabian rivers) favour the development of mangrove ecosystems on the northern coasts of the Arabian Sea and the networks of Neolithic sites around them.

Table 1

Radiocarbon database of sites cited in the paper and used to build the summed probability plots for the regional mangrove development.

\begin{tabular}{|c|c|c|c|c|c|c|c|c|c|}
\hline Site name & Dated material & Origin & Ref. laboratory & ${ }^{14} \mathrm{C}$ date & & Calib. 2 sigm & Sources & Delta R & Country \\
\hline Suwayh-C1 & Marine shell & Geological core (off-site) & Pa 1767 & 4570 & 60 & $2817-2382$ & Lézine et al., 2002 & $235 \pm 30$ & Oman \\
\hline Suwayh-C1 & Marine shell & Geological core (off-site) & Pa 1765 & 5045 & 35 & $3322-3048$ & Lézine et al., 2002 & $235 \pm 30$ & Oman \\
\hline Suwayh-C1 & Marine shell & Geological core (off-site) & Pa 1794 & 5760 & 100 & $4236-3753$ & Lézine et al., 2002 & $235 \pm 30$ & Oman \\
\hline Suwayh-C2 & Marine shell & Geological core (off-site) & Pa 2029 & 5605 & 60 & $3950-3673$ & Lézine et al., 2002 & $235 \pm 30$ & Oman \\
\hline Suwayh-S4-22 & $\begin{array}{l}\text { Shell assemblage } \\
\text { (C. Martin) }\end{array}$ & Geological core (off-site) & Pa 2258 & 5390 & 40 & $3679-3499$ & Berger et al., 2005 & $235 \pm 30$ & Oman \\
\hline Suwayh-S9-24 & $\begin{array}{l}\text { Shell assemblage } \\
\text { (C. Martin) }\end{array}$ & Geological core (off-site) & Pa 2267 & 5910 & 100 & $4354-3938$ & Berger et al., 2005 & $235 \pm 30$ & Oman \\
\hline Bar Al-Hikman C5 & Shell Terebralia palustris & Geological core (off-site) & $\begin{array}{l}\text { Lyon-8527 } \\
\text { (Saca-26476) }\end{array}$ & 5955 & 40 & $4307-4043$ & Berger et al., this paper & $235 \pm 30$ & Oman \\
\hline Alashkara-coupe 5-16 & Wood of Avicennia & Geological core (off-site) & $\begin{array}{l}\text { Lyon-7247 } \\
\text { (SacA, 20342) }\end{array}$ & 6105 & 40 & $5206-4935$ & Berger et al., this paper & No & Oman \\
\hline Alashkara-coupe 5-13 & Wood of Avicennia & Geological core (off-site) & $\begin{array}{l}\text { Lyon-7245 } \\
\text { (SacA, 20340) }\end{array}$ & 5790 & 50 & $4768-4524$ & Berger et al., this paper & No & Oman \\
\hline Alashkara-coupe 5-6 & Wood of Avicennia & Geological core (off-site) & $\begin{array}{l}\text { Lyon-7246 } \\
\text { (SacA, 20341) }\end{array}$ & 5535 & 40 & $4453-4332$ & Berger et al., this paper & No & Oman \\
\hline Alashkara-coupe 5-17 & Unidentified Wood & Geological core (off-site) & $\begin{array}{l}\text { Lyon-7248 } \\
\text { (SacA, 20343) }\end{array}$ & 6410 & 45 & $5475-5309$ & Berger et al., this paper & No & Oman \\
\hline Alashkara-coupe 5-16 & Open lagoon sea shell & Geological core (off-site) & $\begin{array}{l}\text { Lyon-7252 } \\
\text { (SacA, 20381) }\end{array}$ & 5555 & 30 & $3847-3628$ & Berger et al., this paper & $235 \pm 30$ & Oman \\
\hline Alashkara-coupe 5-17 & Open lagoon sea shell & Geological core (off-site) & $\begin{array}{l}\text { Lyon-7251 } \\
\text { (SacA, 20380) }\end{array}$ & 5365 & 30 & $3637-3399$ & Berger et al., this paper & $235 \pm 30$ & Oman \\
\hline Alashkara-coupe 5-18 & Open lagoon sea shell & Geological core (off-site) & $\begin{array}{l}\text { Lyon-7250 } \\
\text { (SacA, 20379) }\end{array}$ & 4845 & 30 & $3003-2755$ & Berger et al., this paper & $235 \pm 30$ & Oman \\
\hline
\end{tabular}


Table 1 (continued)

\begin{tabular}{|c|c|c|c|c|c|c|c|c|c|}
\hline Site name & Dated material & Origin & Ref. laboratory & ${ }^{14} \mathrm{C}$ date & & Calib. 2 sigm & Sources & Delta R & Country \\
\hline Alashkara-coupe 5-19 & Open lagoon sea shell & Geological core (off-site) & $\begin{array}{l}\text { Lyon-7249 } \\
\text { (SacA, 20378) }\end{array}$ & 4195 & 30 & $2132-1880$ & Berger et al., this paper & $235 \pm 30$ & Oman \\
\hline As-Suwayh/Aseelah & Wood of Avicennia & Geological core (off-site) & Unknown & 5650 & 90 & $4054-3644$ & Berger et al., 2005 & No & Oman \\
\hline Ras al-Hamra 6 & Shell Terebralia palustris & Shell middens deposits & Bln-3632/I & 6240 & 70 & $4658-4324$ & Biagi and Nisbet 1992 & $235 \pm 30$ & Oman \\
\hline Ras al-Hamra 6 & Shell Terebralia palustris & Shell middens deposits & Bln-3632/II & 6310 & 60 & $4709-4387$ & Biagi and Nisbet 1992 & $235 \pm 30$ & Oman \\
\hline Ras al-Hamra 6 & Shell Terebralia palustris & Shell middens deposits & Bln-3633/I & 6140 & 60 & $4515-4237$ & Biagi and Nisbet 1992 & $235 \pm 30$ & Oman \\
\hline Ras al-Hamra 6 & Shell Terebralia palustris & Shell middens deposits & Bln-3633/II & 6279 & 60 & $4676-4359$ & Biagi and Nisbet 1992 & $235 \pm 30$ & Oman \\
\hline Ras al-Hamra 6 & Shell Terebralia palustris & Shell middens deposits & Bln-3636/I & 5750 & 60 & $4137-3775$ & Biagi and Nisbet 1992 & $235 \pm 30$ & Oman \\
\hline Ras al-Hamra 6 & Shell Terebralia palustris & Shell middens deposits & Bln-3636/II & 5890 & 60 & $4261-3954$ & Biagi and Nisbet 1992 & $235 \pm 30$ & Oman \\
\hline Ras al-Hamra 6 & Shell Terebralia palustris & Shell middens deposits & Bln-3637/I & 6420 & 80 & $4884-4468$ & Biagi and Nisbet 1992 & $235 \pm 30$ & Oman \\
\hline Ras al-Hamra 6 & Shell Terebralia palustris & Shell middens deposits & Bln-3637/II & 6530 & 80 & $4774-4397$ & Biagi and Nisbet 1992 & $235 \pm 30$ & Oman \\
\hline Ras al-Hamra 6 & Shell Terebralia palustris & Shell middens deposits & Bln-3639/I & 6340 & 60 & $4752-4431$ & Biagi and Nisbet 1992 & $235 \pm 30$ & Oman \\
\hline Ras al-Hamra 6 & Shell Terebralia palustris & Shell middens deposits & Bln-3639/II & 6240 & 60 & $4637-4331$ & Biagi and Nisbet 1992 & $235 \pm 30$ & Oman \\
\hline Ras al-Hamra 6 & Shell Terebralia palustris & Shell middens deposits & Bln-3641/I & 5980 & 60 & $4340-4032$ & Biagi and Nisbet 1992 & $235 \pm 30$ & Oman \\
\hline Ras al-Hamra 6 & Shell Terebralia palustris & Shell middens deposits & Bln-3641/II & 5950 & 60 & $4321-4008$ & Biagi and Nisbet 1992 & $235 \pm 30$ & Oman \\
\hline Saruq; WS5 & Shell Terebralia palustris & Shell middens deposits & Hv-14211 & 6685 & 105 & $5020-4504$ & $\begin{array}{l}\text { Uerpmann and } \\
\text { Uerpmann } 2003\end{array}$ & 425 & Oman \\
\hline Saruq; WS5 & Shell Terebralia palustris & Shell middens deposits & Hv-14970 & 6445 & 100 & $4723-4297$ & $\begin{array}{l}\text { Uerpmann and } \\
\text { Uerpmann } 2003\end{array}$ & 425 & Oman \\
\hline Saruq; WS5 & Shell Terebralia palustris & Shell middens deposits & Hv-14971 & 6275 & 100 & $4756-4312$ & $\begin{array}{l}\text { Uerpmann and } \\
\text { Uerpmann } 2003\end{array}$ & $235 \pm 30$ & Oman \\
\hline Daghmar $1 / 1$ & Shell Terebralia palustris & Shell middens deposits & Hv-10922 & 6545 & 105 & $4834-4356$ & Uerpmann, 1992 & 425 & Oman \\
\hline Wadi Wuttayah & Shell Terebralia palustris & Shell middens deposits & GX-2818 & 7050 & 150 & $5475-4834$ & Biagi 2005 & 425 & Oman \\
\hline Suwayh 1 & Marine shell & Shell middens deposits & Pa 2132 & 6295 & 60 & $4690-4370$ & Charpentier et al., 2003 & $235 \pm 30$ & Oman \\
\hline Suwayh 1 & Marine shell & Shell middens deposits & Рa 2131 & 6050 & 40 & $4397-4164$ & Charpentier et al., 2003 & $235 \pm 30$ & Oman \\
\hline Suwayh 1 sect 3-P 22 & Marine shell & Shell middens deposits & Pa 2135 & 6495 & 50 & $4682-4428$ & Charpentier et al., 2003 & 425 & Oman \\
\hline Suwayh-1 & Marine shell & Shell middens deposits & Pa 2140 & 7245 & 55 & $5483-5364$ & Charpentier et al., 2003 & 425 & Oman \\
\hline Suwayh-1 & Marine shell & Shell middens deposits & Pa 2133 & 6935 & 45 & $5374-5192$ & Charpentier et al., 2003 & 425 & Oman \\
\hline SM10-160-Masirah & $\begin{array}{l}\text { Charcoal of } \\
\text { Rhizophora m. }\end{array}$ & Shell middens deposits & Poz-47254 & 6900 & 100 & $5985-5636$ & $\begin{array}{l}\text { Charpentier et al., } \\
\text { in press }\end{array}$ & No & Oman \\
\hline Suwayh-Trench 4-22 & Cerithidea cingulata & Mechanical trench & Рa 2258 & 5390 & 40 & $3679-3499$ & Berger et al., 2005 & $235 \pm 30$ & Oman \\
\hline Suwayh-Trench $7-23 c$ & Meretrix sp. & Mechanical trench & Pa 2266 & 4955 & 110 & $3358-2774$ & Berger et al., 2005 & $235 \pm 30$ & Oman \\
\hline Suwayh-Trench 9-24 & Marcia marmorata & Mechanical trench & Pa 2267 & 5910 & 100 & $4354-3938$ & Berger et al., 2005 & $235 \pm 30$ & Oman \\
\hline Suwayh-11 & L. Coronata & Shell middens deposits & Pa 1716 & 7275 & 60 & $5705-5484$ & Lézine et al., 2002 & $235 \pm 30$ & Oman \\
\hline Suwayh-11 (un. 8) & Marine shell & Shell middens deposits & Pa 1787 & 6970 & 45 & $5304-5227$ & Charpentier et al., 2000 & 425 & Oman \\
\hline Suwayh-11 (un. 6) & Marine shell & Shell middens deposits & Pa 2136 & 6880 & 30 & $5578-5474$ & Charpentier et al., 2000 & 425 & Oman \\
\hline Ar-Ramlah 6 & Shell Terebralia palustris & Shell middens deposits & Bln-4735 & 6181 & 50 & $4546-4299$ & $\begin{array}{l}\text { Uerpmann and } \\
\text { Uerpmann } 2003\end{array}$ & $235 \pm 30$ & U.A.E \\
\hline Daun 111 & Shell Terebralia palustris & Shell middens deposits & GrN-31492 & 6590 & 45 & $4771-4528$ & Biagi, 2011 & 425 & Pakistan \\
\hline Daun 110 & Shell Terebralia palustris & Shell middens deposits & GrN-31493 & 6690 & 40 & $4887-4669$ & Biagi, 2011 & 425 & Pakistan \\
\hline Daun 1 & Shell Terebralia palustris & Shell middens deposits & GrN-26368 & 6380 & 40 & $4765-4510$ & Biagi, 2011 & $227 \pm 27$ & Pakistan \\
\hline Daun 10 & Shell Terebralia palustris & Shell middens deposits & GrN-31489 & 6305 & 45 & $4691-4431$ & Biagi, 2011 & $227 \pm 27$ & Pakistan \\
\hline Daun 6 & Shell Terebralia palustris & Shell middens deposits & GrN-28802 & 5370 & 35 & $3417-3413$ & Biagi, 2011 & $227 \pm 27$ & Pakistan \\
\hline Daun 5 & Shell Terebralia palustris & Shell middens deposits & GrN-28801 & 4900 & 35 & $3074-2861$ & Biagi, 2011 & $227 \pm 27$ & Pakistan \\
\hline Daun 112 & Shell Terebralia palustris & Shell middens deposits & GrN-32462 & 4625 & 30 & $2751-2465$ & Biagi, 2011 & $227 \pm 27$ & Pakistan \\
\hline Daun 102 & Shell Terebralia palustris & Shell middens deposits & GrN-32117 & 4590 & 35 & $2703-2435$ & Biagi, 2011 & $227 \pm 27$ & Pakistan \\
\hline MH 18 & Shell Terebralia palustris & Shell middens deposits & GrN-31643 & 5790 & 70 & $4212-3818$ & Biagi, 2011 & $227 \pm 27$ & Pakistan \\
\hline Daun 105 & T. telescopium & Shell middens deposits & GrN-32118 & 4470 & 40 & $2549-2253$ & Biagi, 2011 & $227 \pm 27$ & Pakistan \\
\hline Daun 104 & Shell Terebralia palustris & Shell middens deposits & GrN-31490 & 4470 & 35 & $2541-2264$ & Biagi, 2011 & $227 \pm 27$ & Pakistan \\
\hline Daun 101 & Shell Terebralia palustris & Shell middens deposits & GrN-32463 & 4470 & 30 & $2528-2270$ & Biagi, 2011 & $227 \pm 27$ & Pakistan \\
\hline Daun 113 & Shell Terebralia palustris & Shell middens deposits & GrN-31491 & 4455 & 30 & $2488-2233$ & Biagi, 2011 & $227 \pm 27$ & Pakistan \\
\hline Daun 103 & Shell Terebralia palustris & Shell middens deposits & GrN-41243 & 4435 & 40 & $2476-2194$ & Biagi, 2011 & $227 \pm 27$ & Pakistan \\
\hline Gadani & Shell Terebralia palustris & Shell middens deposits & GrN-26369 & 4460 & 30 & $2490-2238$ & Biagi, 2011 & $227 \pm 27$ & Pakistan \\
\hline KKT 2 & Shell Terebralia palustris & Shell middens deposits & GrN-32464 & 6320 & 45 & $4700-4444$ & Biagi, 2011 & $227 \pm 27$ & Pakistan \\
\hline Beri & Shell Terebralia palustris & Shell middens deposits & GrN-32116 & 5960 & 50 & $4320-4042$ & Biagi, 2011 & $227 \pm 27$ & Pakistan \\
\hline THR 3 & Shell Terebralia palustris & Shell middens deposits & GrA-47084 & 5555 & 35 & $3865-3637$ & Biagi, 2011 & $227 \pm 27$ & Pakistan \\
\hline KRM 13 & Shell Terebralia palustris & Shell middens deposits & GrA-47083 & 4635 & 35 & $2821-2469$ & Biagi, 2011 & $227 \pm 27$ & Pakistan \\
\hline Shinzani Creek & Shell T. telescopium & Natural trench & Ly-5134 & 5485 & 95 & $4329-3934$ & Prieur et al., 1991 & $227 \pm 27$ & Pakistan \\
\hline N-Gwadar & Shell Terebralia palustris & Natural trench & Ly-5139 & 5650 & 100 & $4515-4048$ & Prieur et al., 1991 & $227 \pm 27$ & Pakistan \\
\hline
\end{tabular}

\subsubsection{Phase 4 (4400-3900 cal. BC)}

The in-site and off-site radiocarbon dates obtained still indicate the development and exploitation of mangrove ecosystems, but they appear less intense. Some fluctuations of the sea level identified around the Arabian Sea and the Persian Gulf show that eustatic processes may have had an impact on mangrove development.

The climatic transition which occurred in Arabia and across the tropical area at that time must have had an impact on the expansion of the mangrove in the large coastal deltas affected by the AM. The ultimate pollen assemblage of Avicennia sp. is present for this period in the lagoon of Suwayh, studied by Lézine et al. (2002). The occurrence of this arboreal species characteristic of the Mangrove Ecosystems is more diffuse after that point.

We can divide this period into 3 distinct phases:

- Phase 4a (centred on 4400-4250 cal. BC) shows a reduced mangrove development that corresponds to a decrease in the sea level recorded in the Persian Gulf and the Arabian Sea and with an abrupt climatic change well recorded in the speleothem archives of Hoti cave in northern Oman (Fleitmann et al., 2007) (Fig. 10). 


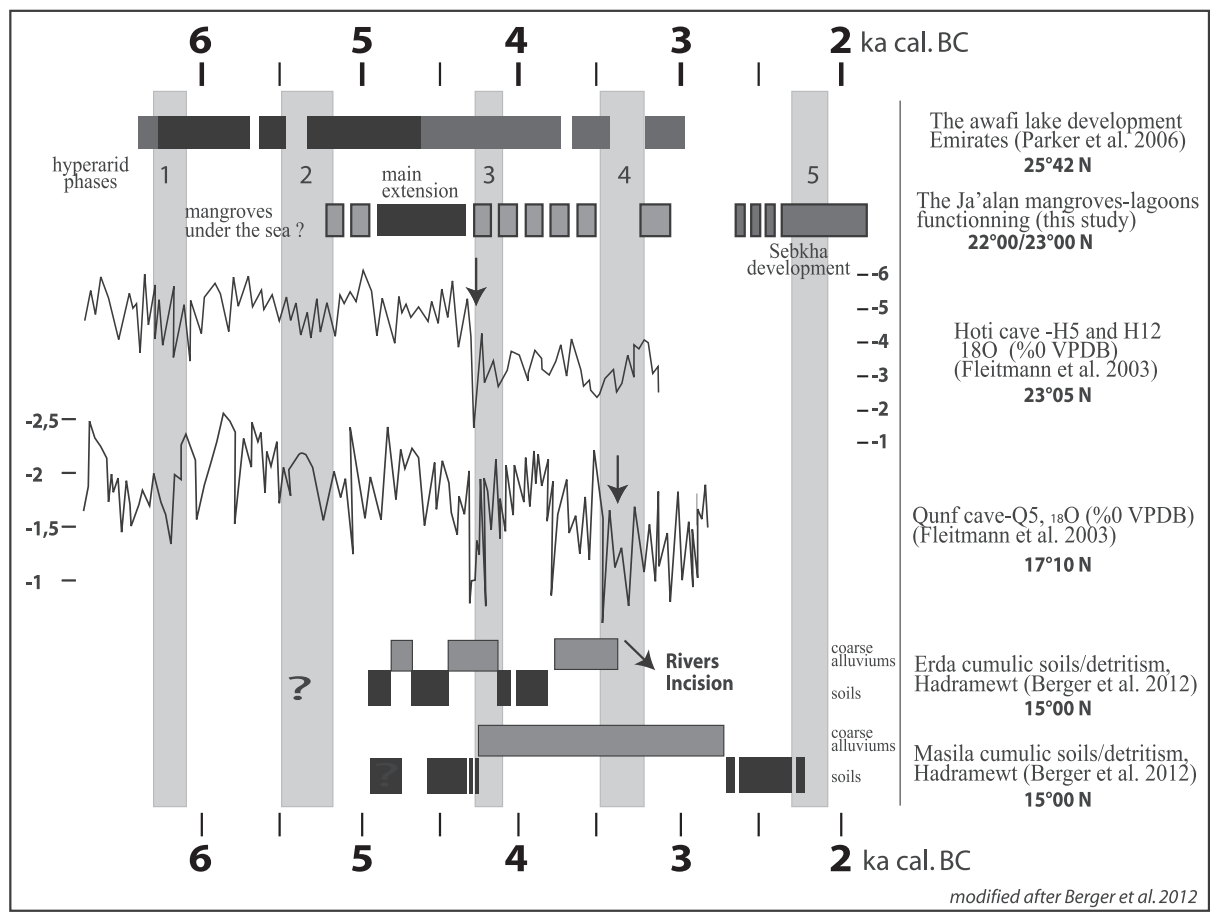

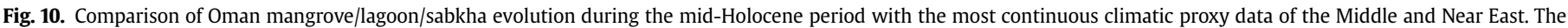

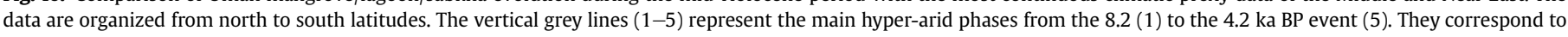

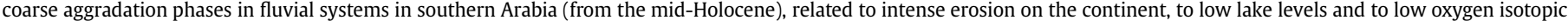
values on speleothems. Soil development appears in relation to lake transgressions and high oxygen isotopic values on speleothems (modified after Berger et al., 2012).

- Phase 4b (4250-4000 cal. BC) records a small peak in mangrove ecosystems development along the Ja'alan and Indus coasts that corresponds to a high sea level in the Ja'alan, Makran and Persian Gulf (Fig. 8).

- Phase 4c (4000-3850 cal. BC) shows a simultaneous decrease of mangrove radiocarbon data and sea level.

\subsubsection{Phase 5 (3800-3500 cal. BC): second optimum of mangrove development}

During this period, relative probability plots of MGE attested by geological archives in the Ja'alan show two secondary peaks that correspond to a strong development of mangrove exploitation in the Indus delta and to a high marine level in the Persian Gulf and in the north of the Gulf of Oman (Makran, India) (Fig. 8). This manifestation of MGE development is less extensive than the first one. All data disappear abruptly after 3500 cal. BC.

\subsubsection{Phase 6 (3500-3000 cal. BC)}

Data are scarce for this last phase. We can divide this period of mangrove occurrence in the Ja'alan region into two.

-Period 6a corresponds to an abrupt decrease in the ${ }^{14} \mathrm{C}$ frequency of mangrove species on the Neolithic sites and in the natural sequences between 3500 and 3250 cal. BC (Fig. 8). This observation is valid for both the eastern Arabian and the Indus coasts. This phase corresponds to a low sea level and a hyper-arid phase in the Arabian peninsula, well recorded in the Awafi Lake in the Emirates and in the river system of the Hadramawt (Yemen), which illustrate an incision dynamic, and in the speleothems records of the Hoti and Qunf caves, which show a strong decrease of the ${ }^{18} \mathrm{O}$ isotopic signal (Fig. 10)
- Phase 6b illustrates a last horizon of mangrove in the sedimentary archives of the Suwayh lagoon around 32003000 cal. BC (Fig. 3A, Berger et al., 2005) before its definite disappearance and replacement by the sabkha system still observed today. Geological signatures are supported by archaeological data from this date, because no shell midden data indicate the presence of MGE predation (by T. palustris or T. telescopium shells or Avicennia sp. charcoals) along this part of the eastern Arabian coast. A low sea level is still associated with this dynamic in the Ja'alan, Makran and Indian regions (Fig. 8).

\subsubsection{Phase 7 (3000/2500 cal. BC to the present)}

Corresponds to the development of sabkhas that are subject to mobile sand invasion because of dominant north-west winds, locally creating barchan-type dunes (Fig. 3B). They replace the beds of grey to blue clays that locally characterize the last phase of the presence of lagoons (Fig. 11B). The sabkha facies shows alternating eolian sands and red clay deposits, which contain strongly indurated gypsum/halite laminae or isolated gypsum crystals (Fig. 11C/ E). The sedimentation rates strongly decrease along the Ja'alan coast. From this period, no archaeological sites provide evidence of the proximal presence of MGE (based on the SWY-3 and RJ-2 malacological studies, which include the second part of the 3rd millennium cal. BC, Martin, 2005).

The occurrence and development of this sabkha can be chronologically defined thanks to coherent dates obtained from three different sites of Ja'alan (Fig. 11A):

- Cores 7 north Suwayh: post $3066 \pm 292$ cal. BC

- Core 1 in the western great sabkha of Suwayh (Lézine et al., 2002): post $2600 \pm 217$ cal. BC 


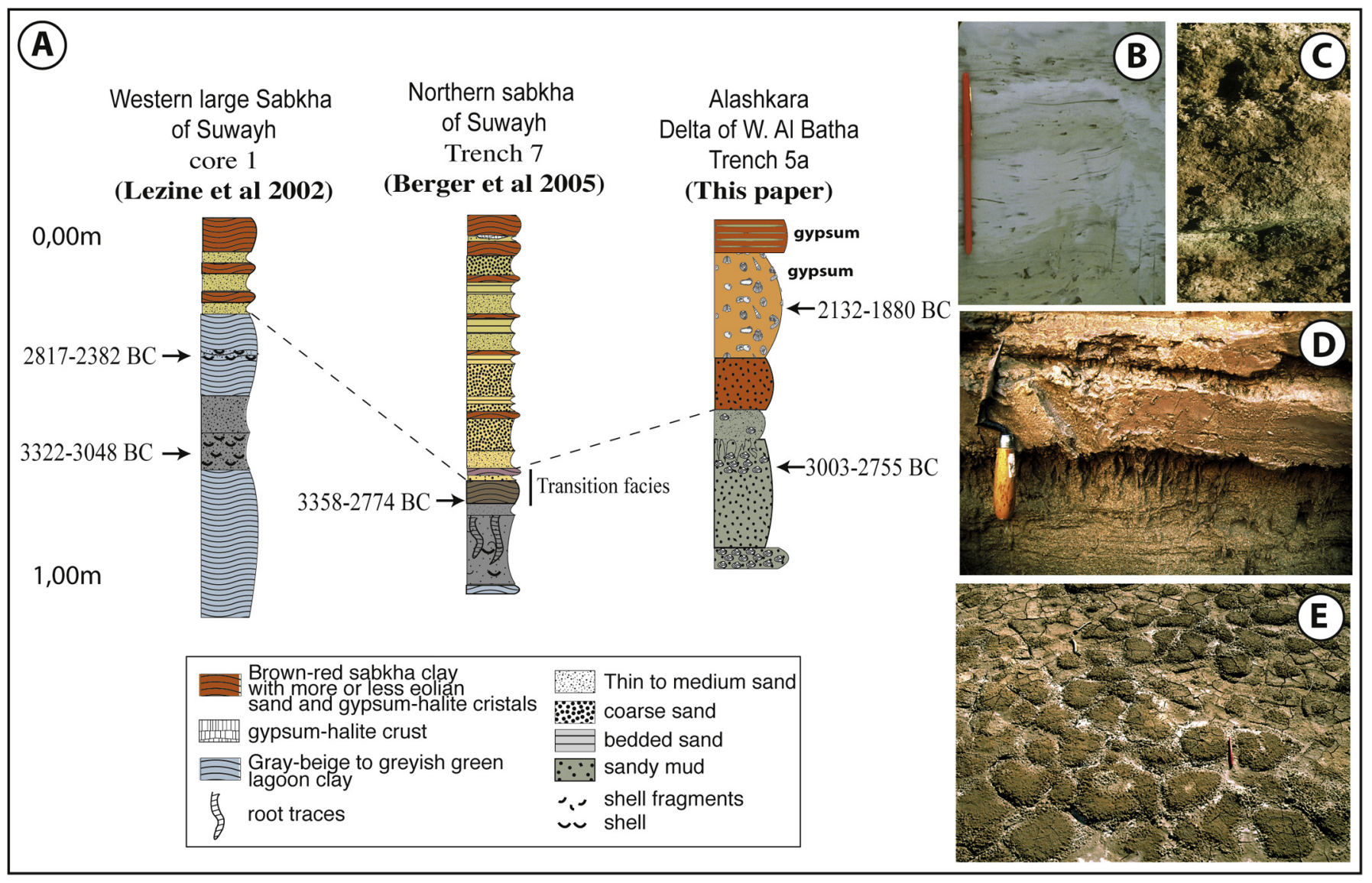

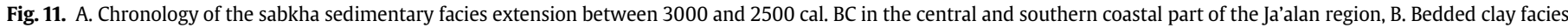

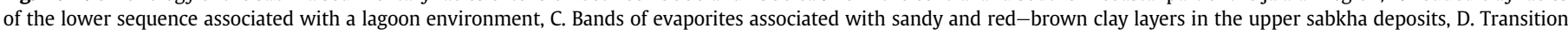

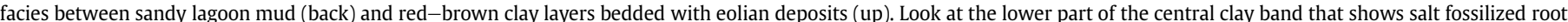

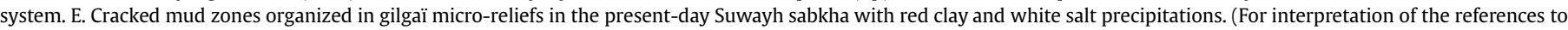
colour in this figure legend, the reader is referred to the web version of this article.)

- They are better dated in the Al-Ashkara-trench 5 in the southern part of the Wadi Al Batha delta: just after $2879 \pm 124$ cal BC and before $2006 \pm 126$ cal. BC.

A beginning date for the sabkha development of the Ja'alan region is suggested for around the middle of the 3rd millennium BC.

\subsection{Palaeogeographical reconstruction and the network of sites along the Ja'alan coast}

The topography of the Ja'alan coast differs considerably between $5000 \mathrm{cal}$. BC and the present day (cf. reconstructions by GIS and site projections). We have the possibility, with GIS simulation of a transgressive marine phase at $8 / 9 \mathrm{~m}$, to reconstruct the possible aspect of the Ja'alan coast during the Neolithic period. This simulation integrates the $2 / 3 \mathrm{~m}$ maximum mid-Holocene sea level, the sedimentary filling-in of old coastal plains $(2 / 3 \mathrm{~m})$ and an approximate $3 / 4 \mathrm{~m}$ rise after the tectonic uplift (not generalized for all the region). We note the systematic association of old khor/ lagoon systems with micro-regional wadis. Neolithic site networks revealed by archaeological field surveys (missions of the Charpentier team since 1998) are preferentially located along the coast between the mangroves/lagoons and the marine beach, for maximum exploitation of the three environments. We observe locally an important concentration of sites around the palaeolagoons or mangroves, sometimes a few kilometres inland
(Fig. 12). They are evidence of past lagoons/mangrove extension during the maximal sea-level rise and the high fluvial activity during the Early to mid-Holocene period.

Our observations reveal that although post-depositional processes are very active and destructive during these extreme events, abandonment of the Ja'alan coast is not attested. Finally, the spatial distribution of the sites along the coast (on deltaic plains, between beaches and mangroves/lagoonal systems...) and the main periods of coastal settlement systems could indicate that these areas were possibly resilient during climatic changes and particularly during the hyper-arid events of the mid-Holocene period (7.3, 6.2, 5.4 and 4.2 ka BP events). In particular, abandonments or changes in occupation strategies are attested on Neolithic shell middens by the replacement of anthropogenic sedimentation dynamics with diffuse cultural deposits, or by occupation layers removed by wind, or by sterile eolian deposits corresponding to hiatuses, such as on the Suwayh 1 or Khuwaymah 2 shell middens (Charpentier et al., 2012a). But only many more radiocarbon dates from Neolithic sites on a micro-regional scale will enable us to better understand these cultural dynamics. These results could be obtained by systematic excavation of trenches in the shell middens, such as those carried out for the last 15 years in the Ja'alan, but this is deterred by the size of the shell middens (sometimes larger than one hectare). The abandonment of part of a shell midden does not mean that the entire site was abandoned. 


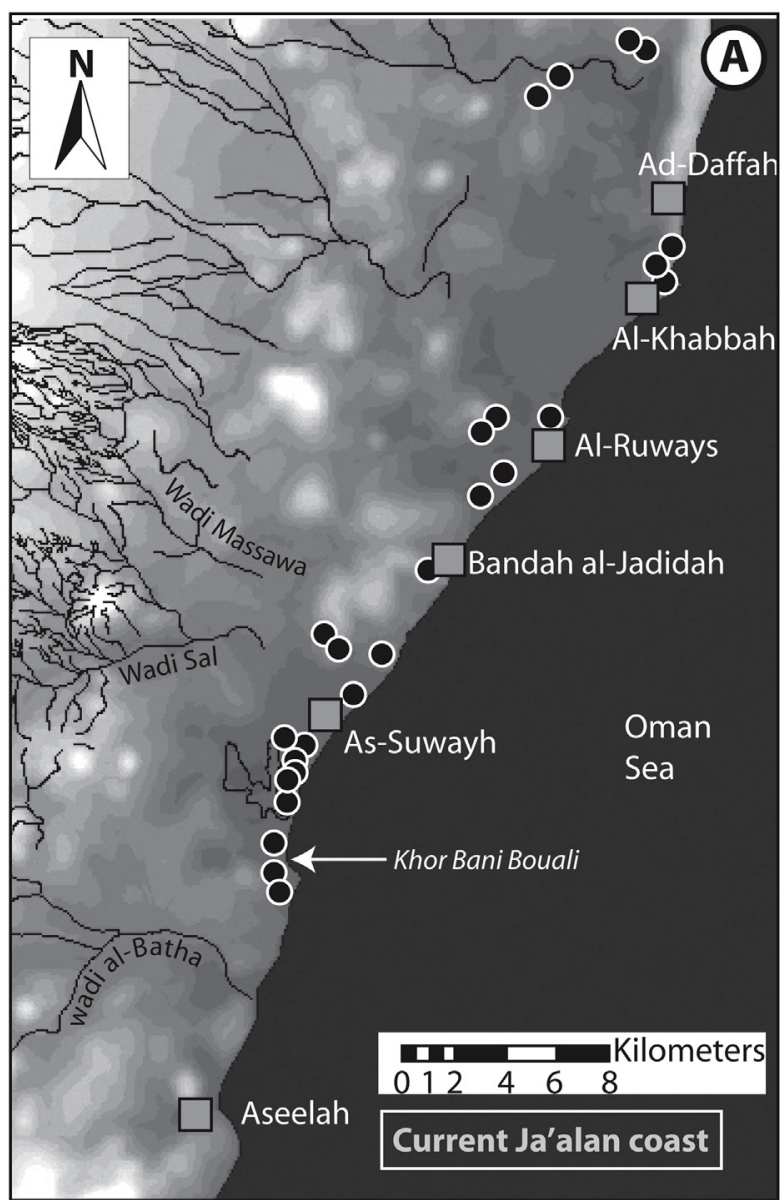

1. Cores SWY 7-9, 2. Cores SWY 1-6, 3. cores 1-2 Lezine et al. 2002, 4. Cores SWY 10-11, 5. cores Alashkara $5 a b$

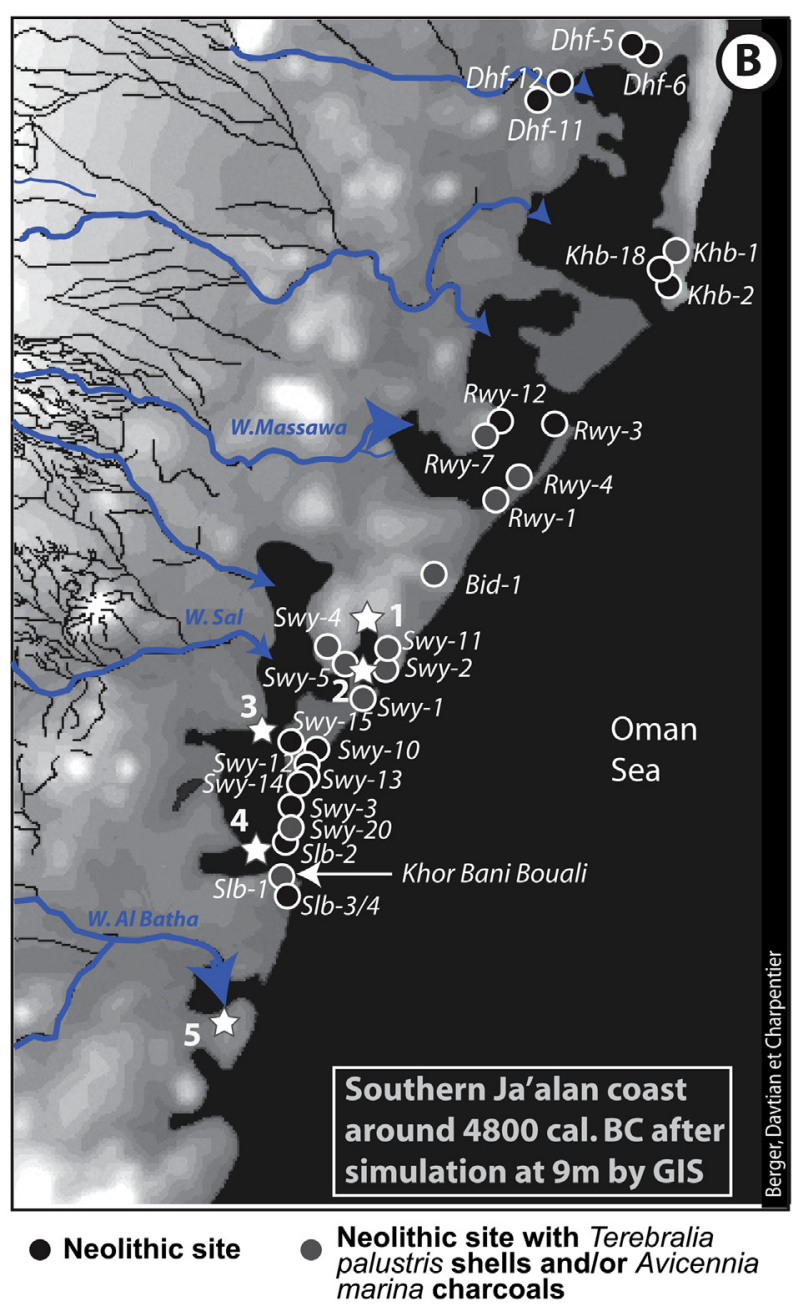

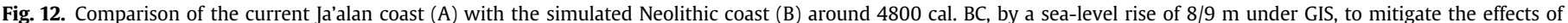
tectonic uplift and coastal sedimentary in filling.

\section{Discussion and conclusions}

The combination of evidence from mangroves and shell middens, from palaeoclimatic data in Arabia and from geomorphological changes due to eustatic variations provides a broad picture of the development of the Ja'alan coastal zone and can help us to understand Neolithic strategies. If we summarize the history of MGE on the eastern coast of Arabia, the mangroves appear to have been mainly under eustatic control during the Early Holocene period and under climatic and partially eustatic/tectonic control starting in the middle of the mid-Holocene. The rapid sea-level rise before $5500 \mathrm{BC}$ (meltpulse $1 \mathrm{~b}$ ) led to dominant marine processes in the most exposed intertidal locations of the Ja'alan which they could not extend to establish zoned forests or accumulated peat. Current and fossil measurements of sedimentation rates in mangrove areas suggest that MGE cannot develop or persist expansively if the sedimentation rate is higher than $12 \mathrm{~cm}$ per century (Ellison and Stoddart, 1991). Thus there were no possible refuge areas for the MGE when rapid sea-level change occurred. The sea-level rise led to the formation of a large embayment in the central coastal zone of the Ja'alan. The optimal mangrove development (4800-3500 cal. BC) associated with this sea-level rise is linked to a considerable rise in Neolithic shell middens along the eastern coast of Arabia and the coast of Las Bela (Baluchistan) and the Indus river delta (Pakistan). These events led to development of diversified economic strategies between marine and lagoon- mangrove ecosystems. A similar situation is observed throughout the major river valleys of Australia between 4800 and 3300 cal. BC (Woodroffe and Grindrod, 1991). Two explanations can be put forward to explain this situation: a wetter climate than the present (very clear in Arabia!) and a response to sea-level stabilization and sedimentation in recently submerged river valleys.

The beginning of the mid-Holocene aridification, mainly as a result of orbital forcing, appears to be well recorded in the shell middens. During the mid-Holocene, eustatic and climatic processes favoured the development and expansion of the MGE along the eastern Arabian coast, as along the Makran coast and the Indus delta more to the north, characterized by two maximal expansion phases between 4800-4400 and 3800-3500 BC. Ideal conditions for mangrove development prevailed during the mid-Holocene when the first extensive mangrove swamps appeared in many tropical areas. This development seems to be of global significance, when sea level was stabilized and monsoon systems became more extensive (Behling et al., 2004; Grindrod et al., 2002; Lézine et al., 2002; Mao et al., 2003; Ellison, 2005; Limaye, and Kumaran, 2012).

The successive hyper-arid phases identified from the analysis of Oman speleothems are in evidence on both archaeological sites (by eolian processes that replace fluvial and paedogenic processes) and in coastal sedimentary systems (by the slowing down or stopping of deltaic progradation, the dehydration and death of mangrove and lagoon ecosystems and their replacement by sabkha environments). The hyper-arid phases centred on 4200 BC, when the M.S. 
moved abruptly to the south of Oman, and on 3400 BC, are wellrecorded in the isotopic proxies of speleothems (Fleitmann et al., 2007) and in the Hadramawt river systems with a definitive entrenchment process around $3400 \mathrm{cal}$. BC, which indicates a major continental hydrological evolution (Berger et al., 2012). This second arid period corresponds to an aridification phase in the Awafi Lake (Parker et al., 2006) and is followed at the end of the 4th millennium by the last traces of large mangrove systems in the Ja'alan (Fig. 10). During this second part of the mid-Holocene, the cyclic upstream depletion of fresh water associated with rapid fluctuations of the sea level led to periodic decreases of MGE expansion, although the mangroves were not able to establish persistent and expansive communities until the sea level had stabilized. Internal geomorphic and sedimentary dynamics are not to be underestimated for this phase. Indeed, sediment accumulated in smaller khors and lagoons at the beginning of the mid-Holocene, reducing their depth and turning them into shallow lagoons that were more sensitive to evaporation processes (Al-Farraj, 2005). The 3rd millennium BC, and more specifically the period from 2500 to $2000 \mathrm{cal}$. $\mathrm{BC}$, corresponds to the expansion phase of sabkha systems in the Ja'alan probably up to the Bar Al-Hikman delta, as a result of the filling of the old lagoons and mangroves, mainly by eolian formations and by drying out. For Lézine et al. (2002), the vegetation landscape in the Ja'alan region is similar to the modern one after 2400 cal. BC, based on a weak decrease in Avicennia pollen, which confirms the installation of a hyper-arid climate. Based on orbital parameter changes, the climate became drier from this period onward in northern tropical areas. Terrestrial sediments transported by northern dominant winds (shamal) then brought wadi sediments into the khor/lagoon environments. These mineral biotopes, sometimes occupied by Salicornia sp., are considered to be poor in biomass for the human coastal communities, and this development certainly modified their strategies. During moister periods that episodically appeared over the last 5 millennia, they could have provided seasonal pastures for grazing systems that appeared in the second part of the Neolithic period and developed throughout the Bronze Age (Cleuziou and Tosi, 2007). The eolian signatures appear permanent in the Ja'alan sabkhas horizons, where they are interbedded with gypsum/halite crusts or red clay levels from 2500 cal. BC onward (Figs. 6 and 11). It is possible that the " 4.2 ka BP abrupt climatic change" impacted the development and the disappearance of mangroves and fresh water lagoons along the eastern Arabian coast. This hyper-arid period is associated in the Arabian peninsula with an abrupt change in the M.S., a strong reactivation of dune formations on the scale of the Arabian peninsula (Bray and Stokes, 2004; Preusser, 2009) and by the eolian dust record of the northern Arabian Sea (Sirocko et al., 1993) and of the Gulf of Oman (Cullen et al., 2000) and an intense detritic and discontinuous activity of the river systems in Yemen due to an irregular ascent of the summer monsoon (Berger et al., 2012). Allochthonous sediment inputs from rivers controlled the development of MGE by modifying shorelines and increasing vertical accretion because of the abundant supply of terrestrially-derived sediment (Ellison and Stoddart, 1991). During this arid episode, our regional data show that the Ja'alan mangroves could have been strongly impacted by these processes, and could have progressively disappeared or survived in a residual state. Local controlling factors, like topography, khor size and sediment availability could have modified the regional tendency (Al-Farraj, 2005). In much larger khors (Al-Jaramah and Bani buali) located north and south of the study area, processes still indicate a khor environment up to the historical period and the present day. But more precise coastal geological data from the second part of the Holocene are still necessary to test this hypothesis and to build a detailed chronology of the Arabian coastal dynamics which are not well established for the last four millennia because of a lack of absolute chronology and organic/shell materials. OSL studies are now necessary.

The MGE then disappeared from the eastern coast of Arabia, with the exception of those still connected to large high watersheds, where sufficient rains could maintain with fresh water the fragile equilibrium of the MGE. From this point in time the coastal economy in Oman was mainly oriented towards sea products, including trade with populations inhabiting interior oasis systems (Cleuziou, 2007).

Mangroves and khor systems supplied with fresh water represented a resource supply when the climate changed, as we note for example on the Suwayh 1 site during the 5th millennium BC. It is still difficult to evaluate the role of fishing in the local and regional economy and which environments were exploited along the Oman coast, mainly because of the lack of ichthyological studies of Neolithic shell middens. We know that ocean winds and currents played a role in the differential distribution of marine resources off the Arabian coasts. Monsoon currents caused coastal ocean upwelling, making certain coastal areas biotically rich, such as the Omani coast (Schott and McCreary, 2001). But productivity in the Arabian Sea is controlled by seasonally reversing monsoonal winddriven upwelling of nutrient-rich deeper waters which fuel phytoplankton growth (Caley et al., 2011). This regional marine resource could represent a permanent supply for the coastal societies of the Ja'alan and of the entire eastern Arabian coast, as has been discussed for others areas (Tompkins and Adger, 2004). What was the future of these sites when mangroves and lagoons disappeared during the 3rd millennium and the population was still growing? The advent of the Bronze Age, with less subsistence economy and more hierarchized societies, was to signify new environmental stresses and new challenges. On the Ja'alan coast, the populations adopted a much more specialized marine economy with coastal to deep-sea exploitation, and intensified regional trade with the development of pastoralism and oasis agriculture in the foothills of the hinterland (Berger et al., 2005; Cleuziou, 2007; Cleuziou and Tosi, 2007).

\section{Acknowledgements}

We warmly thank the French archaeological mission in Oman, under the aegis of the French Ministry of Foreign Affairs ("commission consultative des fouilles à l'étranger"), and Dr. Sultan AlBakri, director of the Department of Excavations and Archaeological Studies, Ministry of Heritage and Culture of Oman. This paper was originally presented at the European Science foundation (exploratory workshop) "The Neolithic of Arabia" colloquium in MOM-Lyon, thanks to the organizers P. Dreschler and R. Crassard. We thank the Centre pour le Radiocarbone of Lyon 1 University and the Laboratoire de Mesure du Carbone 14, UMS 2572, ARTEMIS in Saclay for ${ }^{14} \mathrm{C}$ measurements by SMA in the framework of the National Service to CEA, CNRS, IRD, IRSN and the Ministry of Culture and Communication. RC wishes to thank the Foundation Fyssen ("Subvention de Recherche 2013" grant). And finally many thank to A. Barra for sedimentology analysis, to M. Tengberg for the wood identifications, to L. Purdue for the English corrections of this paper, to Elizabeth Willcox for the rereading of the final version and to Paolo Biagi and an anonymous reviewer for the corrections of this paper. Finally this paper is dedicated to the memory of Serge Cleuziou, who headed the French mission for over 20 years and developed the environmental studies.

\section{References}

Al-Farraj, A., 2005. An evolutionary model for sabkha development on the north coast of the UAE. Journal of Arid Environments 63, 740-755. 
Behling, H., Cohen, M.C.L., Lara, R.J., 2004. Late Holocene mangrove dynamics of Marajó Island in Amazonia, northern Brazil. Vegetation History and Archaeobotany $13,73-80$.

Bell, D.F., 1964. Loss-on-ignition as an estimate of organic matter and organic carbon in non calcareous soils. Journal of Soil Science 15, 84-92.

Belperio, A.P., 1979. Negative evidence for a mid-Holocene high sea level along the coastal plain of the great Barrier Reef Province. Marine Geology 32, 1-9.

Berger, J.F., Cleuziou, S., Davtian, G., Cattani, M., Cavulli, F., Charpentier, V., et al., 2005. Évolution paléographique du Ja'alan (Oman) à l'Holocène moyen: impact sur l'évolution des paléomilieux littoraux et les stratégies d'adaptation des communautés humaines. Paléorient 31 (1), 46-63.

Berger, J.F., Bravard, J.P., Purdue, L., Mouton, M., Benoit, A., Braemer, F., 2012. Rivers of the Hadramawt watershed (Yemen) during the Holocene: clues of late functioning. Quaternary International 266, 142-161.

Biagi, P., 2005. The shell-middens of the Arabian Sea and Gulf: maritime connections in the seventh millennium BP? In: Al-Ansary, A.R., et al. (Eds.), The City in the Arab World: Evolution and Development, pp. 7-16.

Biagi, P., 2011. Changing the prehistory of Sindh and Las Bela coast: twenty-five years of Italian contribution. World Archaeology 43 (4), 523-537.

Biagi, P., 2013. The shell middens of Las Bela coast and the Indus delta (Arabian Sea Pakistan). Arabian Archaeology and Epigraphy, 1-6.

Biagi, P., Nisbet, R., 1992. Environmental history and plant exploitation at the aceramic sites of RH5 and RH6 near the mangrove swamp of Qurum (Muscat Oman). Bulletin de la Societé Botanique Française 139 (2-4), 571-578.

Biagi, P., Nisbet, R., 2006. The prehistoric fisher-gatherers of the western coast of the Arabian Sea: a case of seasonal sedentarization? In: Taylor, Francis (Eds.), Sedentism in Non-agricultural Societies World Archaeology, vol. 38 (2), pp. 220-238.

Bosch, D.T., Dance, S.P., et al., 1995. Seashells of Eastern Arabia. Motivate Publishing, London.

Bray, H.E., Stokes, S., 2004. Temporal patterns of arid-humid transitions in the south-eastern Arabian peninsula based on Optical dating. Geomorphology 59 271-280.

Bronk Ramsey, C., Higham, T.F.G., Owen, D.C., Pike, A.W.G., Hedges, R.E.M., 2002. Radiocarbon dates from the Oxford AMS system: datelist 31. Archaeometry 44 (3), 1-149. Suppl 1.

Caley, T., Malaizé, B., Zaragosi, S., Rossignol, L., Bourget, J., Eynaud, J., Martinez, P. Giraudeau, J., Charlier, K., Ellouz-Zimmermann, N., 2011. New Arabian Sea records help decipher orbital timing of Indo-Asian monsoon. Earth and Planetary Science Letters 308 (3-4), 433-444.

Chapman, V.J., 1976. Mangrove Vegetation. J. Cramer, Vaduz.

Charpentier, V., 2004. Trihedral points: a new facet to the "Arabian Bifacial Tradition". Proceedings of the Seminar for Arabian Studies 34, 53-66.

Charpentier, V., 2008. Hunter-gatherers of the "empty quarter of the early Holocene" to the last Neolithic societies: chronology of the late prehistory of southeastern Arabia (8000-3100 BC). Proceedings of the Seminar for Arabian Studies 38, 59-82.

Charpentier, V., Méry, S., 1997. Hameçons en nacre et limes en pierre d'Océanie et de l'Océan Indien: analyse d'une tendance. Société des Océanistes Vol. 2, 147-156.

Charpentier, V., Angelucci, D., Méry, S., Saliège, J.-F., 2000. Autour de la mangrove morte de Suwayh, l'habitat VIe-Ve millénaires de Suwayh SWY-11, Sultanat d'Oman. Proceedings of the Seminar for Arabian Studies 30, 69-85.

Charpentier, V., Marquis, P., Pellé, E., 2003. La nécropole et les derniers horizons V e millénaire du site de Gorbat al-Mahar (Suwayh, SWY-1, Sultanat d'Oman): premiers résultats. In: Proceedings of the Seminar for Arabian Studies, vol. 33, pp. $11-19$.

Charpentier, V., Méry, S., Phillips, C., 2004. Des coquillages... outillages des Ichtyophages? Mise en évidence d'industries sur Veneridae, du Néolithique à l'âge du Fer (Yémen, Oman, E.A.U.). Arabian Archaeology and Epigraphy 15, $1-10$.

Charpentier, V., Méry, S., Fortini, E., Pellé, E., 2009. « Un chef est un requin qui voyage par terre »: fonctions et statuts des armatures de projectile en dent de Carcharhinus leucas et aiguillon caudal de raie dans l'Arabie des VIe-IIIe millénaires av. notre ère. Arabian Archaeology and Epigraphy 20, 9-17.

Charpentier, V., Berger, J.-F., Crassard, R., Lacaze, M., Davtian, G., 2012a. Prehistory and palaeo-geography of the coastal fringes of the Wahiba Sands and Bar alHikman, Sultanate of Oman. Proceedings of the Seminar for Arabian Studies 42, 57-78.

Charpentier, V., Phillips, C.S., Méry, S., 2012b. Pearl fishing in the ancient world: 7500 BP. Arabian Archaeology and Epigraphy 23, 1-6.

Charpentier, V., Berger, J.-F., Crassard, R., Borgi, F., Davtian, G., Phillips, C.S Conquering new territories: when the first black boats sailed to Masirah Island. Proceedings of the Seminar for Arabian Studies 43, in press.

Cleuziou, S., 2004. Pourquoi si tard? Nous avons pris un autre chemin: l'Arabie des chasseurs-cueilleurs de l'Holocène au début de l'âge du bronze. In: Guilaine, Jean (Ed.), Aux marges des grands foyers du Néolithique: Périphéries débitrices ou créatrices? Errance, Paris, pp. 123-148.

Cleuziou, S., 2007. Evolution towards complexity in a coastal desert environment: Early Bronze Age in the Ja'alan, Sultanate of Oman. In: Kohler, T., Van de Leeuw, S.E. (Eds.), Modeling Long-term Culture Change. Santa Fe Institute Publications, SAR Press, pp. 209-228.

Cleuziou, S., Tosi, M., 2007. In the Shadow of the Ancestors. The Prehistoric Foundations of the Early Arabian Civilization in Oman, Muscat.

Crassard, R., Drechsler, P., 2013. Towards new paradigms: multiple pathways for the Arabian Neolithic. Arabian Archaeology and Epigraphy 24 (1).
Cullen, H., deMenocal, P.B., Hemming, S., Hemming, G., 2000. The possible role of climate in the collapse of the Akkadian Empire: evidence from the deep sea. Geology 28 (4), 379-382.

de Beauclaire, R., Jasim, S.A., Uerpmann, H.P., 2006. New results on the Neolithic jewellery from al-Buhais 18, UAE. Proceedings of the Seminar for Arabian Studies 36, 175-187.

Desse, J., Desse-Berset, N., 2005. Les Ichthyophages du Makran (Belouchistan, Pakistan). Paléorient 31 (1), 86-96.

Dornkamp, J.C., Brunsden, D., Jones, D.K.C., 1980. Geology, Geomorphology and Pedology of Bahrain. Geo Abstracts Ltd, Norwich.

Dutta, K., Bhushan, R., Somayajulu, B.L.K., 2001. $\Delta$ R correction values for the northern Indian ocean. Radiocarbon 43 (2A), 483-488.

Ellison, J.C., 2005. Holocene palynology and sea-level change in two estuaries in Southern Irian Jaya. Palaeogeography, Palaeoclimatology, Palaeoecology 220, 291-309.

Ellison, J.C., Stoddart, D.R., 1991. Mangrove ecosystem collapse during predicted sealevel rise: Holocene analogues and implications. Journal of Coastal Research 7, $151-165$.

Evans, G., Kendall, V., Bush, P., Nelson, H., 1969. Stratigraphy and geologic history of the sabkha, Abu Dhabi, Persian Gulf. Sedimentology 12, 145-159.

Fleitmann, D., Burns, S., Mangini, A., Mudelsee, M., Kramer, J., Villa, I., Neff, U., AlSubbary, A., Buettner, A., Hippler, D., Matter, A., 2007. Holocene ITCZ and Indian monsoon dynamics recorded in stalagmites from Oman and Yemen (Socotra). Quaternary Science Reviews 26, 170-188.

Grindrod, J., Moss, P., van der Kaars, S., 2002. Late Quaternary mangrove pollen records from continental shelf and ocean cores in the North Australian-Indonesian region. In: Kershaw, P., et al. (Eds.), Bridging Wallace's Line: the Environmental and Cultural History and Dynamics of the SE- Asian - Australian Region, Catena, Reiskirchen, pp. 119-146.

Hutchings, P.A., Recher, H.F., 1983. The faunal communities of Australian mangroves. In: Teas, H.J. (Ed.), Biology and Ecology of Mangroves. Junk Publications, The Hague, pp. 103-110.

Kumaran, K.P.N., Nair, K.M., Shindikar, M.R., Limaye, R.B., Padmalal, D., 2005. Stratigraphical and palynological appraisal of the Late Quaternary mangrove deposits of west coast of India. Quaternary Research 64, 418-431.

Lézine, A.M., Saliège, J.-F., Mathieu, R., Tagliatela, T.L., Méry, S., Charpentier, V., Cleuziou, S., 2002. Mangroves of Oman during the late Holocene: climatic implications and impact on human settlements. Vegetation History and Archaeobotany 11 (3), 221-232.

Lézine, A.M., Robert, C., Cleuziou, S., Inizan, M.L., Braemer, F., Saliège, J.F., Sylvestre, F., Tiercelin, J.J., Crassard, R., Méry, S., Charpentier, V., Steimer-Herbet, T., 2010. Climate evolution and human occupation in the Southern Arabian lowlands during the last deglaciation and the Holocene. Global and Planetary Change, 412-428.

Limaye, R.B., Kumaran, K.P.N., 2012. Mangrove vegetation responses to Holocene climate change along Konkan coast of south-western India. Quaternary International. http://dx.doi.org/10.1016/j.quaint.2012.01.034s.

Mao, L., Zhang, Y., Bi, H., 2003. Mangrove vegetation changes since Mid-Holocene in a coastal swamp of Northern Hainan Island, China. Journal of Geosciences 46, 135-155.

Martin, C., 2005. The shell material from Suwayh 1 (Oman, Neolithic). In: Bar-Yosef (Ed.), Archaeomalacology: Molluscs in Former Environments of Human Behaviour. Proceedings of the 9th ICAZ Conference, Durham 2002. Oxbow Books, Oxford, pp. 166-177.

Martin, C., Matsukuma, A., 2006. A new Meretrix species from Arabian Sea. Venus. Japanese Journal of Malacology 65 (3), 270-271.

McClure, H.A., Vita-Finzi, C., 1982. Holocene shorelines and tectonic movements in eastern Saudi Arabia. Tectonophysics 85, 37-43.

Méry, S., Marquis, P., 1999. Un habitat côtier de l'Âge du Bronze à Khor Bani Bu Ali SWY-3 (Sultanat d'Oman) - deuxième campagne de fouille. Bulletin of the Society for Arabian Studies 4, 9-12.

Méry, S., Charpentier, V., Auxiette, G., Pellé, E., 2009. A dugong bone mound: the Neolithic ritual site on Akab in Umm al-Quwain, United Arab Emirates. Antiquity $83,696-708$.

Oliver, G., 1992. Bivalved Seashells of the Red Sea. National Museum of Wales, Cardiff.

Parker, A.G., Preston, G.W., 2008. Early to Middle Holocene climate change and vegetation dynamics in the northern Oman Peninsula: an ecogeographical synthesis of the Jebel al-Buhais environment. In: Uerpmann, H.-P., Uerpmann, M., Jasim, S.A. (Eds.), The Natural Environment of Jebel Al-Buhais: Past and Present. The Archaeology of Jebel al-Buhais, Sharjah, United Arab Emirates, vol. 2. Kerns Verlag, Tübingen, pp. 71-81.

Parker, A.G., Goudie, A.S., Stokes, S., White, K., Hodson, M.J., Manning, M., Kennet, D., 2006. A record of Holocene climate change from lake geochemical analyses in southeastern Arabia. Quaternary Research 66, 465-476.

Pirazzoli, P.A., 1991. World Atlas of Holocene Sea-level Changes. Elsevier Oceanography Series, Amsterdam.

Preusser, F., 2009. Chronology of the impact of Quaternary climate change on continental environments in the Arabian Peninsula. Comptes Rendus Geoscience 341, 621-632.

Prieur, A., Evin, J., Besenval, R., Sanlaville, P., 1991. Evolution de la région littorale du Makran pakistanais à l'Holocène. Paléorient 17, 3-18.

Saliège, J.-F., Lezine, A.-M., Cleuziou, S., 2005. Estimation de l'effet réservoir ${ }^{14} \mathrm{C}$ marin en mer d'Arabie. Paléorient 31 (1), 64-69.

Sanlaville, P., Dalongeville, R., 2005. L'évolution des espaces littoraux du Golfe Persique et du Golfe d'Oman depuis la phase finale de la transgression postglaciale. Paléorient 31 (1), 9-26. 
Schott, F.A., McCreary, J.P.J., 2001. The monsoon circulation of the Indian Ocean. Progress in Oceanography $51,1-123$.

Sirocko, R., Sarnthein, M., Erlenkeuser, H., Lange, H., Arnold, M., Duplessy, J.C., 1993. Century-scale events in monsoonal climate over the past 24,000 years. Nature 364, 322-324.

Staubwasser, M., Sirocko, F., Grootes, P., Erlenkeuser, H., 2002. South Asian monsoon climate change and radiocarbon in the Arabian Sea during early and middle Holocene. Paleoceanography 17 (4), 1063.

Tengberg, M., 2005. Les forêts de la mer. Exploitation et évolution des mangroves en Arabie orientale du néolithique à l'époque islamique. Paléorient 31 (1), 39-45.

Tompkins, E.L., Adger, W.N., 2004. Does adaptive management of natural resources enhance resilience to climate change? Ecology and Society 9 (2), 10.

Uerpmann, M., 1992. Structuring the Late Stone Age of Southeastern Arabia. Arab. Arch. Epig. 3, 65-109.

Uerpmann, H.-P., Uerpmann, M., 2003. Stone Age Sites and Their Natural Environment. In: The Capital Area of Northern Oman. Part III. Beihefte zum Tiibinger Atlas des Vorderen Orients. ReiheA. Naturwissenschaften, Tübingen.
Uerpmann, H.-P., Uerpmann, M., 2009. Early fishers and herders: the Neolithic period in the UAE. In: New Perspectives on Recording UAE History. Center for Documentation and Research, Abu Dhabi.

Uerpmann, H.-P., Uerpmann, M., Jasim, S.A., 2006. Funeral Monuments and Human Remains from Jebel Al-Buhais, vol. 1. Kerns Verlag, Tübingen.

Uerpmann, H.-P., Potts, D., Uerpmann, M., 2009. Holocene (re-)occupation of eastern Arabia. In: Petraglia, M.D., Rose, J.I. (Eds.), Evolution of Human Populations in Arabia: Paleoenvironments, Prehistory and Genetics. Springer Dordrecht, pp. 205-214.

Uerpmann, M., de Beauclair, R., Händel, M., Kutterer, A., Noack, E., Uerpmann, H.-P., 2012. The Neolithic site FAY-NE15 in the central region of the Emirate of Sharjah (UAE). Proceedings of the Seminar for Arabian Studies 42, 385-400.

Vita-Finzi, C., 1998. Ancient shorelines of Oman and Qatar. In: Phillips, C.S., Potts, D.Y. Searight, S. (Eds.), Arabia and Its Neighbours. Essays on Prehistorical and Historical Development Presented in Honour of Beatrice de Cardi (Brepols), pp. 263-272.

Woodroffe, C.D., Grindrod, J., 1991. Mangrove biogeography: the role of Quaternary environmental and sea-level change. Journal of Biogeography 18, 479-492. 